March 14, 1893.

\title{
Sir W. H. Flower, K.C.B., LL.D., F.R.S., President, in the Chair.
}

The Secretary read the following report on the additions to the Society's Menagerie during the month of February 1893 :-

The total number of registered additions to the Society's Menagerie during the month of February was 73, of which 43 were by presentation, 6 by birth, 10 by purchase, 10 received in exchange, and 4 on deposit. The total number of departures during the same period, by death and removals, was 91 .

Amongst the additions attention may be called to two Terrapins procured at Okinawa Shima, or Great Loochoo Island, by Mr. P. A. Holst, and kindly presented by that gentleman. Mr. Holst writes that Dr. L. Döderlein has stated in a paper read before the Asiatic Society that he could find no Tortoises whatever on the Loochoo Islands. Mr. Holst has therefore forwarded these specimens in order to show that Tortoises are certainly found there.

$\mathrm{Mr}$. Boulenger has kindly determined these Tortoises as being Spengler's Terrapin, Nicoria spengleri (Boul., Cat. of Chelonians, 1889, p. 120).

Mr. Oldfield Thomas exhibited a specimen of what he believed to be Nanotragus livingstonianus, Kirk, which had been obtained by Mr. A. H. Neumann in Northern Zululand in April 1892. The species had only previously been known from a very imperfect scalp and skull obtained by Sir John Kirk at Shupanga on the Zambesi and described by him in the Proceedings of the Society ${ }^{1}$. Although the horns of this Zululand specimen, and also those of a second example which $\mathrm{Mr}$. Neumann had generously presented to the National Collection, were stouter and heavier, without being longer, than those of the type, Mr. Thomas had little hesitation in referring them to the same spécies, the difference appearing to be merely one of age.

$N$. livingstonianus, as evidenced by Mr. Neumann's two perfect specimens, differed from its near ally, N. moschatus, Von Düb., the Zanzibar Antelope, in its decidedly larger size and thicker horns, also in the much greater extension of the bony palate posteriorly behind the molars, and in its much brighter and more rufous colour. In this last respect there was a considerable difference between the two, the general colour above of $N$. moschatus being dull fawn-grey, while in $N$. livingstonianus it was rich rufous verging on chestnut; the flanks and legs also were far brighter and more rufous. In the length of the ears and their coloration, and in the general distribution of the body and limb colours, there appeared to be a close agreement between the two species; the tail of $N$. livingstonianus was, however, much more decidedly black above than that of $N$. moschatus. 
The dimensions of Mr. Neumann's specimen, taken on the stuffed animal, a fully adult male, were as follows :-

Height at withers $348 \mathrm{~mm}$. (=13.75 inches). Length of head and body round curves, 596 ; ears from notch, 93 ; hind foot, without hoof, 170 ; tail, 76 . Length of body (chest to rump in a straight line), 419.

Skull-basal length, 111 ; greatest length, 124 ; greatest breadth, 59 ; gnathion to orbit, 60 ; muzzle in front of teeth, 32 ; length of tooth-series, $38 \cdot 5$; palate, length, 71 .

Horns, length 87, circumference at base 50 .

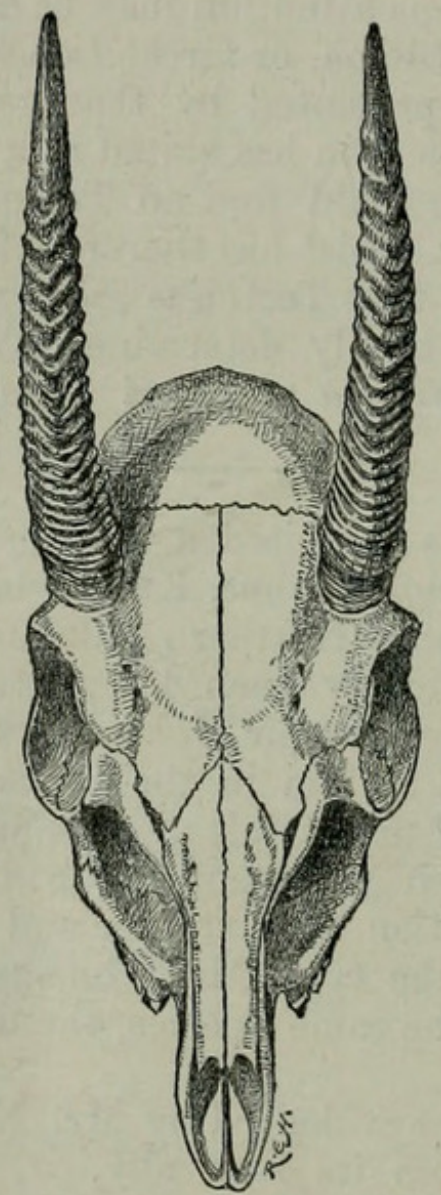

Head of Nanotragus livingstonianus.

In the 'Field' for September last year ${ }^{1}$ Mr. Neumann had written an account of the distribution and habits of this Antelope, and had there stated that its native Zulu name was "Inhlengane," that its ordinary habitat was the bushy parts of the low country between the coast and the Bombo range, and that the present specimen, which had been killed on the Umkuzi River, represented the extreme southerly limit of its range. Further north he had heard of it in the neighbourhood of the Lower Limpopo and Komati rivers ; and Mr. Thomas's present identification of it with

1 'Field,' lxxx. p. 368, Sept. 1892. 
$N$. livingstonianus carried its northern range onwards to the Zambesi.

Mr. Neumann stated that the species had a very strong musky odour, which presumably came from the suborbital glands, and also that there were in this species very well marked interdigital pits.

Dr. C. J. Forsyth Major exhibited a tooth of an Ant-bear (Orycteropus) from the Upper Miocene of Maragha (Persia), and made the following remarks :-

"The tooth, of which I present a sketch (see woodcut), forms part of a small collection of Mammalian remains from Maragha (Persia), sent to the British Museum, together with remains of several other interesting Mammals from the same deposit, by M. R. Damon ${ }^{1}$.

"As to its belonging to Orycteropus - of which it is apparently an antepenultimate right lower molar-there cannot be the least doubt, there being no other Mammal that presents this general form, as well as the minute structure, which was compared by Cuvier with the section of a cane, and is produced by the polygonal prisms of dentine, each of which has a tubular pulp-cavity in its centre.
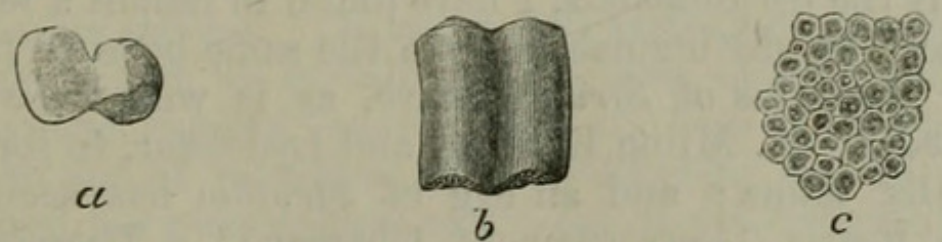

Lower molar of Orycteropus gaudryi.

$a$. Top view; $b$. Side view; $c$. Part of lower surface, much magnified.

"With regard to the specific determination, up to the present date only one fossil form of this genus is known, namely Orycteropus gaudryi, Major, from the Upper Miocene of the isle of Samos. The size of the Maragha tooth is that of the Samos form, viz. about one fifth smaller than that of the living species. As the present known fauna of Maragha, which is not numerous, has not less than 13 species in common with Samos, I feel myself fairly entitled to apply the same specific name to the fossil from Maragha.

"Apart from the size, there are but small differences between the fossil and the recent species of Orycteropus. The upper profile of the skull is more horizontal in the fossil form. The lachrymal is more elongate and absolutely longer in the smaller Miocene form, the relative proportion in the length of the two being as $23: 21.5$ millim.; in the recent species this bone is almost square.

1 See Quart. Journ. Geol. Soc. for May 1886, pp. 173-176. 
"The anterior teeth, which $\mathrm{O}$. Thomas ${ }^{1}$ has shown to be premolars, are stouter and more numerous in the fossil than in the adult recent species, there being four premolars above and below, and, moreover, in the mandibula an eighth tooth, which, as to its position and shape, may be considered to be the homologue of a canine. In the upper jaw the anterior part of the snout is broken, but there must doubtless have existed a canine too.

"The bones of the pes present no differences from those of the now living forms, with the exception of the first and fifth metatarsals, which are somewhat stouter in the fossil, a fact which leads to the supposition that there is in the recent Orycteropus a tendeney towards the reduction of the digits.

"Thus, on the whole, the fossil approaches closely its African congeners, and gives us no clue as to what might have been the ancestral form of the genus, which we place amongst the Edentates, there being no suitable place for it anywhere else.

"There was a time when Marsupials, Edentates, Lemuroids, and Ratitce were considered as proots of the former existence of an Antarctic continent, from which, their original home, they were believed to have spread northwards, peopling the various Continents in which they actually exist. Of late years, however, one after the other of these groups have been discovered in the Tertiary deposits of the Northern Hemispheres, in Europe and America. As regards the Struthionida, I have found in Samos a femur which can scarcely be distinguished from the same bone of the African Struthio. Remains of Struthio have, as is well known, likewise been stated, by A. Milne Edwards and Lydekker, to form part of the Siwalik fauna; and an egg of Struthio has been found in Southern Russia (Gouvernement Cherson) ${ }^{2}$. Therefore a more natural explanation of the present distribution of the groups above mentioned is to consider the southern points of the present continental masses as their last refuges, to which they have been driven by later invaders from the North ${ }^{3}$.

"The presence of Orycteropus in the Ethiopian fauna had remained unexplained. The facts adduced this evening show that during the Upper Miocene representatives of this genus existed as far north and eastwards as the isle of Samos and Eastern Persia."

The following papers were read:-

1 Oldfield Thomas, "On the Milk Dentition in Orycteropus," Proc. Roy. Soc. London, vol. xlvii. 1890 , pp. 246-248.

2 Struthiolithus chersonensis, Brandt.

${ }^{3}$ Cf. Haacke (Biolog. Centralblatt, vi. p. 363). 
1. Suggestions for the more definite use of the word "Type" and its compounds, as denoting Specimens of a greater or less degree of Authenticity. By Oldfield Thomas, F.Z.S.

[Received February 14, 1893.]

As systematic zoology becomes more and more exact and detailed, the great value of the actual specimens to which specific names have been applied, $i$. e. the "types," has been more and more appreciated, but at the same time the word itself has been applied by different authors so loosely and to specimens of such very varied degrees of authenticity, that it seems as though an exact definition of the term were somewhat of a desideratum, and that at the same time it would be of great convenience to have by means of compounds of the word "type" a set of names each applying definitely to some particular class of specimens. The word "type" itself when first introduced was meant to refer to the particular specimen (in the singular) originally described, but it soon was naturally applied to any individual of the original series, if more than one specimen was exanined by the describer. In this there was little cause for confusion, but more recently it has been applied to any individual from the collection of the original author, obtained no matter how much later, and often not even determined by him as belonging to his species. Of late a still further cause of confusion has been introduced by certain authors who, obtaining specimens from the typical locality, have spoken of them as "typical specimens," a method of reference which, although due to a praiseworthy regard for geographical exactness, is yet certainly liable to give rise to inconvenience and confusion.

But it will be readily admitted that these various classes of specimens have each a certain value in relation to their respective species, and, as the best means of obviating the confusion above referred to, it appears advisable that they should have definite names showing their greater or less degree of closeness to the true original type.

Already, as a step towards this end, the word "co-type" has been introduced ${ }^{1}$ for any specimen which was one of several forming the basis of the original description; but, like "type," it has become loosely and vaguely used for different sorts and classes of specimens, and equally needs definition and pinning down to one particular class, for which alone it should be used.

So far as regards their original material, species may be described in one or other of the three following ways :-

I. On a single specimen, no others being seen.

III. On two or more specimens, no one of them being selected as the "type."

III. On a specimen selected out of a series of two or more, and specially mentioned at the time as the "type."

${ }^{1}$ I believe in the first case by my colleague Mr. C. O. Waterhouse. 
As to category I. there is or ought to be no confusion whatever. The one specimen, and that alone, is the "type," no matter how many specimens the original collector may afterwards send home, or the original author afterwards determine.

In the case of category II., all the specimens on which the author based his species, be they many or few (but no specimens received or named afterwards), would be " co-types," there being then no single "type" of the species at all, as all the co-types may be supposed together to form the type.

In the case of category III., as the author has selected his type, that, and that alone, would remain as such, but since the other specimens mentioned or enumerated by him in the original description are of unquestionably great value in a typical sense, they ought also to have a name and might be called "para-types" (or side-types).

Next, to meet the case of specimens collected afterwards at the same place as the originals, and having thus at least a local claim to authenticity, the word topo-type (or place-type) might be suggested, but it should, so far as possible, be restricted to specimens collected within, say, a few miles of the original typical locality.

In addition, it may be thought that specimens received from the original locality after the first description is published, but verified as belonging to his own species by the describer of it himself, should have a peculiar name, and for such there might be suggested the name "meta-type" (or after-type). As, however, we know from experience that it is by no means impossible for the author of a name to apply it wrongly, such meta-types would be of but little more value than simple topo-types, especially if determined long after the first description of the species.

The following are, then, the definitions now suggested for the different terms :-

A Type is a single specimen either unaccompanied by others at the time of description, or else deliberately selected as such by the author out of a series.

A Co-type is one of two or more specimens together forming the basis of a species, no type having been selected. No species would have both type and co-types, but either the former, or two or more of the latter.

A Para-type is a specimen belonging to the original series, but not the type, in cases where the author has himself selected a type. It should, however, be one of the specimens mentioned or enumerated in the original description.

A Topo-type is a specimen simply collected at the exact locality where the original type was obtained.

A Meta-type is a specimen received from the original locality after the description has been published, but determined as belonging to his own species by the original describer himself. 


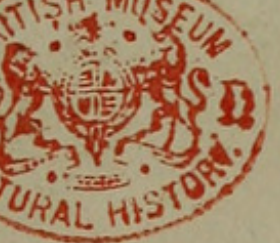




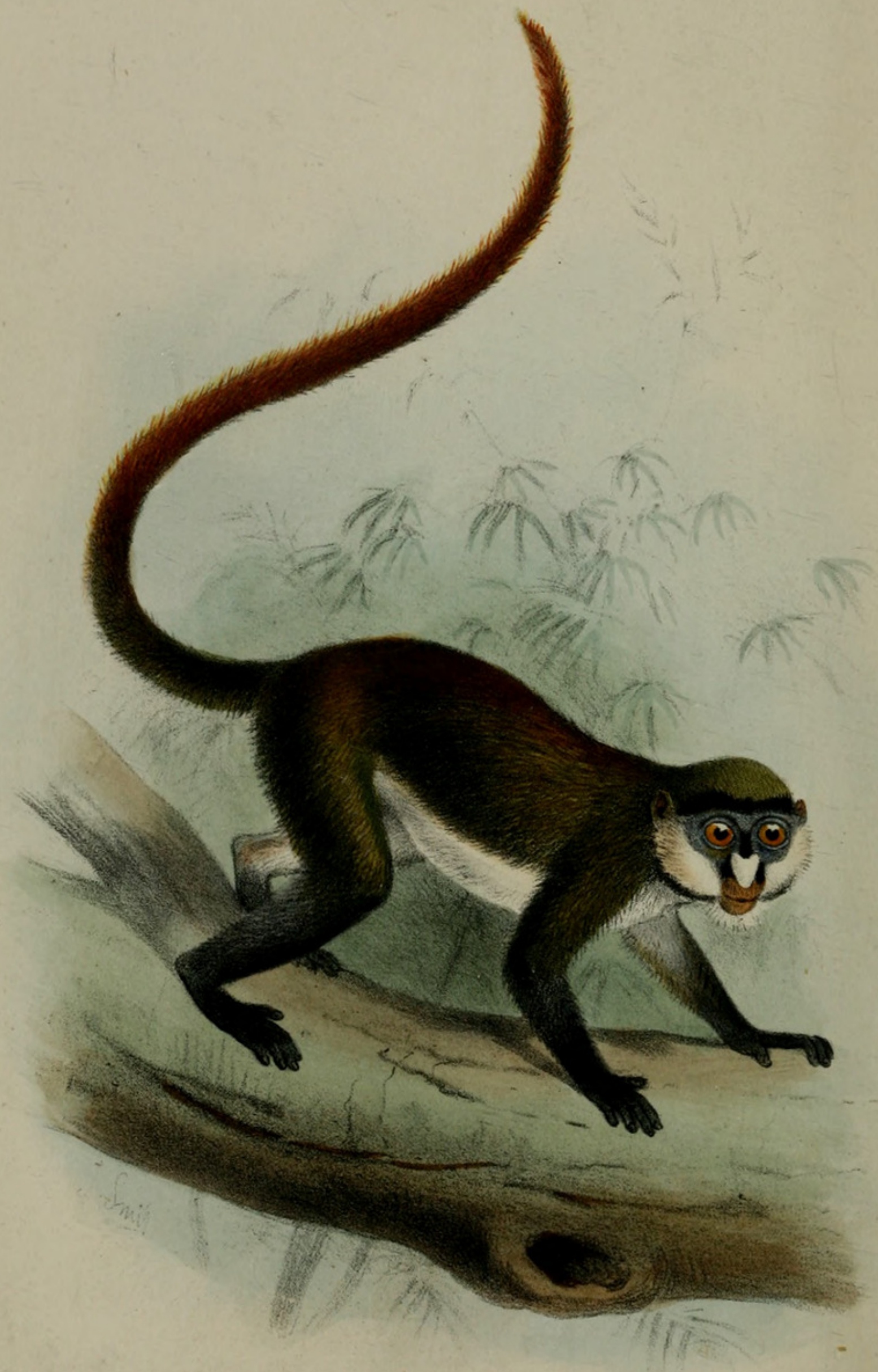


$47 \cdot 0=0$

THAL HIST 


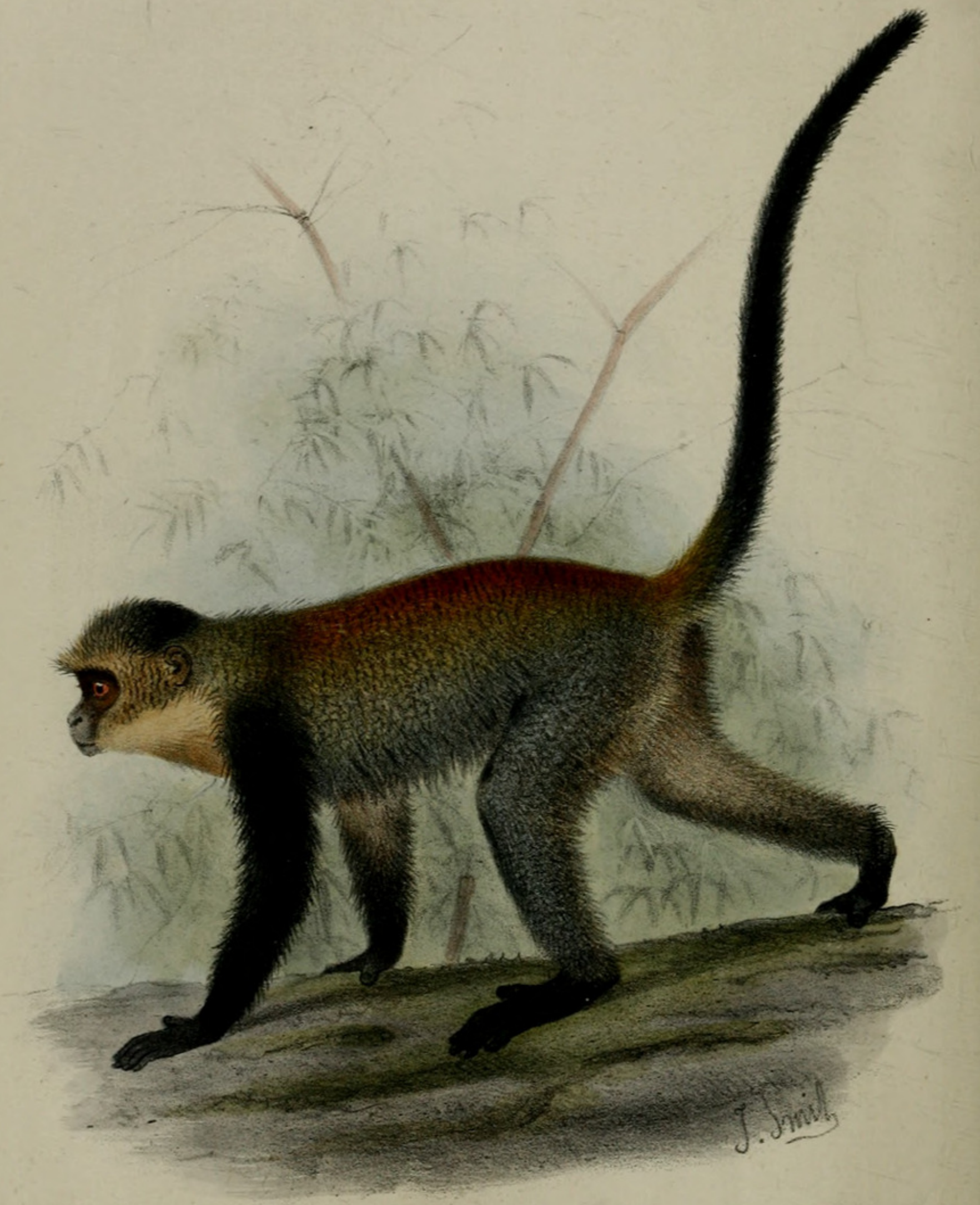


2. On a new African Monkey of the Genus Cercopithecus, with a List of the known Species. By P. L. Sclater, M.A., Ph.D., F.R.S., Secretary to the Society.

[Received March 8, 1893.]

\section{(Plates XVI. \& XVII.)}

Since the Monkeys of the characteristic Æthiopian genus Cercopithecus were reviewed by Martin ${ }^{1}$, Geoffroy St.-Hilaire ${ }^{2}$, Wagner ${ }^{3}$, Gray ${ }^{4}$, and Schlegel ${ }^{5}$, many additions have been made to the series. Having had occasion to look up the recent contributions to our knowledge of this subject, I have thought that it might save future workers some trouble if $I$ ask the Society to accept for publication a new list of the described species, drawn up while I have been endeavouring to find names for some EastAfrican members of this group which have lately come under my notice.

The species of Cercopithecus ${ }^{6}$ are obviously very local in their distribution, and in many cases apparently confined to narrowly restricted areas. I have therefore added under the head of each species a short record of the positively ascertained localities in which it has been procured. I have also indicated the species of which we have received living examples in the Society's Gardens.

I have not included Myopithecus (with the last inferior molar with three tubercles only) and Cercocebus (with the last inferior molar with five tubercles) in my list, but only the typical Cercopitheci (with the last inferior molar with four tubercles).

Of this genus as limited by Geoffroy St.-Hilaire some 45 species have been described. I will divide these into two categories:those of which I have personally examined specimens, and those which I know only from their published descriptions.

The 31 species known to me may be divided for convenience of treatment into six sections as follows :-

Sect. A. Rhinosticti.

Species.

With a distinct nose-spot, white, blue, or red .. $\quad 1-9$

1 Martin, 'General Introduction to the Natural History of Mammiferous Animals.' London, 1841.

${ }^{2}$ Geoffroy St.-Hilaire, in d'Orb. Dict. univ. d'Hist. nat. iii. p. 296 (1843).

3 Wagner, Säugeth. v. p. 38 (1855).

4 Gray, Catalogue of Monkeys, \&c. p. 20 (1870).

${ }^{5}$ Schlegel, Mus. d. Pays-Bas, Simice, p. 68 (1876).

6 The generic name Cercopithecus, though used by Ray, Klein, and Brisson, and in a binomial sense by Erxleben, appears to have been first restricted to the African group of Monkeys to which it is now universally applied by Martin in his 'Natural History of Mammiferous Animals' (1841). Cercopithecus is a good classical term. Martial says (Epigr. xiv. 202) :-

"Callidus emissas eludere Simius hastas,

"Si mihi cauda foret, Cercopithecus eram." 
Sect. B. Chloronoti.

Species.

Above olive-green; beneath white $\ldots \ldots \ldots \ldots$ 10-15

Sect. C. Erythronoti.

Above rufous; beneath white $\ldots \ldots \ldots \ldots \ldots 16,17$

Sect. D. Melanochiri.

Arms, hands, and feet black ........... 18-26

Sect. E. Auriculati.

Ears with long tufts $\ldots \ldots \ldots \ldots \ldots \ldots \ldots, 27-29$

Sect. F. Barbati.

With a long pointed white beard $\ldots \ldots \ldots \ldots$ 30, 31

Sect. A. Cercopitheci rhinosticti.

The nine species of the "spot-nosed" group with which I am acquainted may be diagnosed as follows :-

A. Naso piloso, albo.

a. Pectore albo.

$a^{\prime}$. Cauda non rufescente.

$a^{\prime \prime}$. Brachiis cinereis.

$a^{\prime \prime \prime}$. Genis albis.

$\{$ Capite nigro cincto

Capite post. unicolore

$b^{\prime \prime \prime}$. Genis olivaceis

$b^{\prime \prime}$. Brachiis nigris

1. petaurista.

2. buettikoferi.

3. martini.

$b^{\prime}$. Cauda rufescente.

$\{$ Genis anguste nigris

$\{$ Genis late nigris

4. ludio.

b. Pectore cinereo

5. melanogenys.

6. schmidti.

7. nictitans.

B. Naso piloso, rubro

C. Naso semi-nudo, cæruleo

8. erythrotis.

9. cephus.

\section{Cercopithecus petaurista.}

Simia petaurista, Schreb. Säug. i. p. 103, t. xix. B (1775).

Cercopithecus petaurista, Erxl. Syst. Reg. An. p. 35 (1777); Martin, M. An. p. 539 ; Geoffr. Dict. univ. d'Hist. nat. iii. p. 301; Wagn. Säug. Suppl. v. p. 50 (1855) ; Gray, P. Z. S. 1868, p. 182; id. Cat. Monk. B. M. p. 20 (1870); Schleg. Mus. P.-B. vii. p. 86 (1876); Scl. List Vert. (1883) p. 13.

Ascagne (Cerc. ascanius), F. Cuv. Mamm. i. pl. 18 (?).

Hab. Gold Coast (Mus. Lugd.).

This is one of the commonest of the Cercopitheci in captivity. We have always examples of it living in the Gardens. The black line which passes above the ears and borders the crown behind serves to distinguish this species from all its allies. The sharply defined white of the lower surface of the tail is another peculiar character of $C$. petaurista.

2. Cercopithecus buettikoferi.

Cercopithecus büttikoferi, Jentink, Notes Leyd. Mus. viii. p. 56 (1886).

Hab. Liberia (Büttikofer).

This species, described from specimens in the Leyden Museum, 
is closely allied to $C$. petaurista, but has no black band round the back of the head. There are two skins, received from Leyden, in the British Museum.

\section{Cercopithecus martini.}

Cercopithecus martinii, Waterh. P.Z. S. 1838, p. 58, et 1841, p. 71 ; Martin, M. An. p. 542 ; Wagn. Säug. Suppl. v. p. 50 (1855) (footnote); Gray, P. Z. S. 1868, p. 182 ; id. Cat. Monk. B. M. p. 21 (1870); Scl. P. Z. S. 1884, p. 176, pl. xiv.

$H a b$. Fernando Po or adjacent coast.

This Monkey is easily distinguishable from $C$. petaurista by its greenish cheeks, without any white stripe beneath the ears, the bluish skin on the face, the greenish colour of the tail above, and the black hands and feet. We have a fine living specimen (received Feb. 19, 1884) now in the Society's Menagerie.

\section{Cercopithecus ludio.}

Cercopithecus ludio, Gray, P.Z. S. 1849 , p. 8, pl. ix. fig. 1, et 1862, p. 182 ; id. Cat. Monk. B. M. p. 21 (1870); Wagn. Säug. Suppl. v. p. 51 (1855); Scl. List Vert. (1883) p. 13.

Hab. West Africa: Delta of Niger (Baikie); Cameroons (Crosstey).

I have examined the specimens of this species in the British Museum, including the type which is badly figured (l.s. c.). I believe it to be a good species, characterized by its black limbs and rufous rump.

We had a specimen of this Monkey living in the Gardens in 1871, of which there is a coloured sketch by Smit in the Library. We have since received other individuals, but have not always distinguished them from the allied species.

\section{Cercopithecus melanogenys.}

Cercopithecus melanogenys, Gray, Ann. \& Mag. N. H. xvi. p. 212 (1845) ; id. P. Z. S. 1849 , p. 7, pl. ix. fig. 2, et 1868, p. 182 ; id. Cat. Monk. B. M. p. $21(1870)$; Wagner, Säug. Suppl. v. p. 50 (1855); Scl. P.Z.S. 1860 , p. 246 ; Monteiro, P.Z.S. 1860, p.112; Jent. Notes L. M. x. p. 11 (correct descr.).

\section{Hab. Angola (Monteiro).}

The type of this species (badly figured $l$. s. c.) is in the British Museum. It has the lower cheeks black, a spot between the eye and ear whitish, and the tail-end rufous.

\section{Cercopithecus schmidis. (Plate XVI.)}

Cercopithecus ascanias (?), Scl. P.Z. S. 1887, p. 502.

Cercopithecus schmidti, Matschie, Zool. Anz. p. 161 (1892).

$H a b$. Int. Eastern Africa; Manyuema, west of Tanganyika (Schmidt); Uganda (Stuhlmann).

A skin of this species has been lately received at the British 
Museum from Berlin. It is closely allied to C. melanogenys, but differs in having only a very narrow black streak beneath the conspicuous white cheeks, the fur above more punctulated, and a much brighter rufous tail.

There can be no doubt that the Monkey which I described in 1887 from a specimen formerly living in the Society's Menagerie, and referred doubtfully to C. ascanias, belonged to C. schmidti. I now exhibit a coloured sketch of this individual (Plate XVI.) taken by Mr. Smit in 1884. This specimen, presented by the Rev. W. C. Willoughby in December 1883, was originally obtained in Manyuema. It died in November 1886.

\section{Cercopithecus nictitans.}

Simia nictitans, Linn. Syst. Nat. i. p. 40 (1766).

Cercopithecus nictitans, Erxl. Syst. Regn. An. p. 35 (1777); Martin, Monk. p. 536 ; Geoffr. Dict. univ. d'Hist. nat. iii. p. 301 ; Wagn. Säug. Suppl. p. 50 (1855) ; Gray, P. Z. S. 1868, p. 182; id. Cat. Monk. B. M. p. 21 (1870); Schleg. Mus. P.-B. vii. p. 89 (1876); Scl. List Vert. (1883) p. 12.

Hocheur (Cercopithecus nictitans), F. Cuv. Hist. Nat. Mamm. i. pl. 17 (1825).

$H a b$. West Africa.

This Monkey is distinguished from all the other species of the section known to me by the absence of black stripes on the face, by the grey under surface, and by the peculiar shape of the white nose-spot, which is narrowed above and broadened below.

It is not uncommon in captivity, and we have had some 10 or 12 specimens of it during the past thirty years, but I know of no anthentic record of the exact district of West Africa in which it is found wild.

\section{Cercopithecus erythrotis.}

Cercopithecus erythrotis, Waterh. P. Z. S. 1838, p. 59, et 1841, p. 71; Martin, M. An. p. 535 ; Fraser, Zool. Typ. pl. iv. (1848); Wagn. Säug. Suppl. v. p. 49 (1855); Gray, P. Ż. S. 1868, p. 182 ; id. Cat. Monk. B. M. p. 21 (1870); Schleg. Mus. P.-B. vii. p. 70 (1876); Scl. P. Z. S. 1884, p. 176.

$H a b$. Fernando Po (Fraser).

This species is quite unmistakable from its red nose (of which the upper portion is sparingly covered with red hairs), reddish ears, and bright ferruginous red tail. We first received a living specimen of it in 1884, and another in 1885 . The former lived until January 1888. I exhibit its skin.

\section{Cercopithecus cephus.}

Simia cephus, Linn. Syst. Nat. i. p. 39 (1766).

Moustac (Cercopithecus cephus), F. Cuv. Hist. Nat. Mamm. i. pl. 19 (1821).

Cercopithecus cephus, Martin, M. An. p. 532; Wagn. Säug. Suppl 
v. p. 49 (1855) ; Gray, P. Z. S. 1868 , p. 182 ; id. Cat. Monk. B. M. p. 20 (1870); Schleg. Mus. P.-B. vii. p. 91 (1876).

Hab. Gaboon and Congo (Mus. Lugd.); Cabonda (Monteiro).

The Moustache Monkey is also readily distinguishable by its naked blue nose and yellowish cheek-tufts. It is often brought alive to Europe, and we have had many specimens of it living in the Monkey-house. Schlegel gives Gaboon and Congoland for its localities; we have received living examples procured by Monteiro in Cabonda, just north of the Congo.

\section{Sect. B. Cercopitheci chloronoti.}

The Green Monkeys known to me are six in number. They are all more or less of an olivaceous green above and white beneath. Their arms and legs are greyish, not black. They may be shortly diagnosed as follows :-

A. Facie carnea

10. cynosurus.

B. Facie nigra.

a. Frontis fascia alba.

$a^{\prime}$. Ano concolore.

$\{$ Mystacibus elongatis albis : scroto cæruleo ... 11. griseo-viridis.

\{Mystacibus modicis flavidis : seroto viridi ... 12. callitrichus.

$b^{\prime}$. Ano rufescente.
$\{$ Dorso olivaceo
13. lalandii.
Dorso flavicanti-olivaceo..........................
14. pygerythrus.
15. erythrarchus.

b. Frontis fascia alba nulla

\section{Cercopithecus cynosurus.}

Simia cynosuros, Scop. Delic. Flor. Faun. Insubr. i. p. 44, t. xix. (1786).

Malbrouck (Cercopithecus cynosurus), F. Cuv. Hist. Nat. Mamm. i. pl. 24 (1819).

Cercopithecus cynosurus, Martin, M. An. p. 515; Geoffr. Dict. univ. d'Hist. nat. iii. p. 306 ; Wagn. Säug. Suppl. v. p. 38 (1855); Schleg. Mus. P.-B. vii. p. 72 (1876) ; Scl. List Vert. (1883) p. 5.

Chlorocebus cynosurus, Gray, Cat. Monk. B. M. p. 26 (1870).

Hab. West Africa: Senegambia? (Schlegel).

The Malbrouck is one of the commonest of this genus of Monkeys in captivity. During the past ten years we have had at least 25 specimens of it. It is at once recognizable, when alive, by its pale flesh-coloured face, and the blue scrotum of the male.

Schlegel believes that Senegambia is its true patria, but this is a point upon which further information is required. I find it included in Rochebrune's list ('Faune de la Sénégambie,' Mamm. p. 33), but I fear his authority is hardly reliable.

\section{Cercopithecus Griseo-riridis.}

Simia sabcea, Linn. Syst. Nat. i. p. 38 (1766)?

Cercopithecus sabcus, Geoffr. Cat. Prim. p. 22 ; Schleg. Mus. P.-B. vii. p. 74 (1876).

Chlorocebus engythithia, Gray, Cat. Monk. B. M. p. 26 (1870). 
Cercopithecus griseo-viridis, Desm. Mamm. p. 61 (1820); Martin, M. An. p. 518; Blanford, Zool. Abyss. Exp. p. 224 ; Scl. List Vert. (1883) p. 6.

Grivet (Cerc. griseus), F. Cuv. Mamm. i. pl. 22 (1819).

$H a b$. East Africa: Abyssinia (Rüppell and Blanford); Sennaar (Clot-Bey).

There is a great difference of opinion as to what the Simia sabcea of Linnæus refers to. It is therefore better to reject the name altogether, and to call this species griseo-viridis. The "Grivet" is also pretty common in captivity, but not so frequently imported as the Vervet and Green Monkey. Its long white whiskers and the blue scrotum of the male distinguish it from $C$. callitrichus, its West-African representative.

\section{Cercopithecus callimrichus.}

Cercopithecus callitrichus, Geoffr. Cat. p. 23; Schl. Mus. P.-B. Simice, p. 73 ; Scl. List Vert. (1883) p. 7.

Callitriche (Cerc. sabceus), F. Cuv. Mamm. i. pl. 21.

Cercopithecus sabceus, Wagn. Säug. v. p. 40 ; Martin, M. An. p. 519.

Chlorocebus sabceus, Gray, Cat. Monk. p. 25.

Hab. Senegambia (Mus. Lugd.); Liberia (scarce, Büttikofer).

The Green Monkey is, I think, the commonest of this section in captivity next, perhaps, to the Vervet. We have generally a good supply of specimens of both these species, which do well in our Gardens. The yellow-tinged and shorter whiskers and the green scrotum of the male distinguish the Green Monkey from the Grivet.

The Green Monkey has been introduced in some of the WestIndian islands, and has become an indigenous species there. See my notes on this subject, P. Z. S. 1866, p. 79. It is said also to have been introduced into St. Iago-one of the Cape Verd group (Schl. Mus. P.-B. Simiae, p. 74).

\section{Cercopithecus lalandif.}

Cercopithecus lalandii, Geoffr. Dict. univ. d'Hist. nat. iii. p. 305; id. Cat. Prim. p. 21 ; Wagner, Säug.v. p. 39 ; Scl. List Vert. (1883) p. 6.

Cercopithecus pygerythrus, Martin, M. An. p. 521; Schl. Mus. P.-B. Simice, p. 76 .

$H a b$. South Africa, Cape Colony.

"The Vervet is closely allied to the Malbrouck and Grivet, so that a little care and attention are necessary to enable the observer to discriminate between them. It differs, however, from both in having the fur long, and rather coarse, and of a much greyer tint, the wash of olive being less decided, in the tail being black, nearly throughout its whole length; and in the superciliary bristles being very conspicuous. From the Malbrouck it may be distinguished by the muzzle being less thick and heavy, and from the 
Grivet by the rust-red hairs on the space below the root of the tail." (Martin, op. cit.)

The Vervet is one of the commonest species of this genus brought to Europe alive.

\section{Cercopithecus pygerythrus.}

Vervet (Simia pygerythra), F. Cuv. Mamm. i. pl. 23 (1821).

Cercopithecus pygerythrus, Desm. Mamm. Suppl. p. 534 (1820); Geoffr. Cat. Prim. p. 21; Wagn. Säug. v. p. 39 ; Peters, Reise n. Moss., Säug. p. 4 (Zambesia); Thomas, P. Z. S. 1885, p. 219 (Kilimanjaro).

Cercopithecus rufo-viridis, Scl. List Vert. (1883)p. 8 ; id. P.Z. S. 1860, p. 420.

Hab. East Africa, from Mozambique to Kilimanjaro.

If $\mathrm{I}$ am correct in identifying this species with the true $C$. pygerythrus it is a very close ally of the Vervet (C. lalandii), and differs mainly in its yellowish-green colour above. I have until recently called this species $C$. rufo-viridis, and am not now quite clear that it is C.pygerythrus; but I am inclined to think so from what Wagner says (l.s. c.).

\section{Cercopithecus erythrarchus.}

Cercopithecus erythrarchus, Peters, Reise n. Moss., Säug. p. 1, pl. 1; Schleg. Mus. P.-B. Sim. p. 77 ; Kirk, P. Z. S. 1864, p. 649 (Zambesi) ; Reuvens, Zool. Gart. xxx. p. 207 (Zambesi); Oudemans, Zool. Gart. xxxi. p. 267.

Hab. Mozambique (Peters); Lower Zambesi (Kirk).

Apparently quite distinct from the preceding species, being without any white frontal band and having the lower rump rufous. We have a young living specimen now "on deposit" in the Monkey-house which, I suspect, belongs to this species. It is said to have been obtained on the Congo.

\section{Sect. C. Cercopitheci erythronoti.}

Of this section, which is at once recognizable by members of it being bright rufous above and white beneath, only two species are known to me, which may be discriminated as follows :-
A. Supra ruber flavido mixtus; naso nigro
16. patas.
B. Supra ruberrimus; naso albo
17. pyrrhonotus.

\section{Cercopithecus patas.}

Simia patas, Schreb. Säug. t. xvi. (1774).

Cercopithecus patas, Erxl. Syst. R. An. p. 34 ; Schleg. Mus. P.-B. vii. p. 84 (1876); Scl. List Vert. (1883) p. 8.

Simia rubra, Gm. Syst. Nat. i. p. 34 (1788).

Cercopithecus ruber, Geoffr. Ann. d. Mus. xix. p. 96 (1812); id. Dict. univ. d'Hist. nat. iii. p. 307 ; Martin, M. An. p. 509; Wagn. Säug. Suppl. v. p. 42 (1855); Scl. P. Z. S. 1874, p. 664; id. List Vert. (1883) p. 8. 
Patas (Simia rubra), F. Cuv. Hist. Nat. Mamm. i. pl. 25 (1820).

Chlorocebus ruber, Gray, Cat. Monk. B. M. p. 25 (1870).

Hab. West Africa: Senegal (Mus. Lugd.).

The Patas is subject to a certain amount of individual variation, and I was at one time of opinion that it might be possible to distinguish two forms of this species ( $c f$. P. Z. S. 1874, p. 664). It is much more comwon in captivity than the Nisnas.

\section{Cercopithecus pyrrhonotus.}

Cercopithecus pyrrhonotus, Hempr. et Ehr. Symb. Phys. pl. x.; Geoffr. Dict. univ. d'Hist. nat. iii. p. 307; Wagn. Säug. v. p. 42; Scl. P. Z. S. 1871, p. 623 ; id. List Vert. (1883) p. 8; Schleg. Mus. P.-B. Sim. p. 84.

Cercopithecus ruber, Rüpp. Neue Wirbelth. p. 8.

Nisnas, F. Cuv. Hist. Nat. Mamm. i. pl. 27 (1830).

Hab. Kordofan and Darfour (Rüppell); Somaliland (Soc. Zool. Viv.).

We have received altogether seven examples of the Nisnas, which is quite distinct from the Patas when seen alive. A fine male, presented Sept. 29 th, 1882 , by Mrs. F. Dixon, was stated to have been brought from Somaliland.

\section{Sect. D. Cercopitheci melanochiri.}

The nine species referred to this section, all of which have the arms and legs black or dark cinereous, may be diagnosed as follows:-

A. Pectore albo.

a. Striga femorali alba

$b$. Striga femorali nulla.

$\{$ Dorso toto concolore; ano rufo

Dorso postico cum ano nigro

B. Pectore cinereo.

c. Maculis auricularibus nullis.

Dorso concolore

Dorso postico brunneo

d. Macula utrinque ad aures rubra

C. Pectore rubro

D. Pectore nigro.

Striga femorali alba; fronte nigro

Striga femorali nulla; fronte albo cincta

18. mona.

19. albigularis.

20. campbelli.

18. Cercopithecus mona.

Simia mona, Schreb. Säug. i. p. 97, t. xv. (1775).

Cercopithecus mona, Erxl. Syst. Reg. An. p. 32 (1777) ; Martin, M. An. p. 527 ; Wagn. Säug. Suppl. v. p. 47 (1855); Gray, P.Z. S. 1868, p. 182 ; id. Cat. Monk. B. M. p. 22 (1870); Sel. List Vert. (1883) p. 9 ; Schleg. Mus. P.-B. vii. p. 80 (1876).

Mone (Cercopithecus mona), F. Cuv. Hist. Nat. Mamm. i. pl. 15 (1819).

Hab. West Africa: Cameroons (Mus. Lugd.).

The Mona is easily recognized by the white patch on the thighs, on each side of the tail, and the white band on the forehead. It 
is not uncommon in captivity; we have had some 25 specimens of it since 1860.

\section{Cercopithecus albigularis.}

Semnopithecus? albogularis, Sykes, P.Z. S. 1831, p. 106.

Cercopithecus albogularis, Sykes, P.Z.S. 1832, p. 18; Martin, M. An. p. 512 ; Fraser, Zool. Typ. pl. ii. (1848); Wagn. Säug. Suppl. v. p. 45 (1855); Gray, P.Z. S. 1868, p. 182 ; id. Cat. Monk. B. M. p. 24 (1870); Schleg. Mus. P.-B. vii. p. 79 (1876); Scl. List Vert. (1883) p. 9 ; True, Pr. U.S. Nat. Mus. xv. p. 448 (Kilimanjaro).

$H a b$. East Africa, Kilimanjaro (Abbott): Gold Coast (Pel).

Sykes's. Monkey, as this species is commonly called, is also frequently brought alive to this country. We have had some 25 specimens in the Menagerie during the past thirty years.

It belongs to the Mona group, but has no white thigh-patches, and the rump is more or less rufous.

Schlegel gives the locality of this species as Gold Coast $(P e l)$; but it appears certainly to occur in East Africa, and it would be desirable that specimens from these countries should be compared.

\section{Cercopithecus dampbelli.}

Cercopithecus campbelli, Waterh. P.Z. S. 1838, p. 61 ; Fraser, Zool. Typ. pl. iii. (1848); Martin, M. An. p. 544; Wagn. Säug. Suppl. v. p. 47 (1855); Gray, P.Z.S. 1868, p. 182 ; id. Cat. Monk. B. M. p. 24 (1870); Schleg. Mus. P.-B. vii. p. 81 (1876); Scl. List Vert. (1883) p. 11; Jent. Notes L. M. x. p. 9 (Liberia).

Cercopithecus burnetti, Gray, Ann. N. H. x. p. 256 (1842).

$H a b$. West Africa: Gold Coast (Pel); Liberia (Büttil.), common.

Campbell's Monkey is by no means so common in captivity as the two preceding species. We have had, so far as our modern registers go, only eight examples of it.

It is easily distinguishable from C. albogularis by the black rump and outer surface of the thighs. It has a frontal band like the Mona, but tinged with rufous.

\section{Cercopitheous samango.}

Cercopithecus samango, Sundev. Öfvers. K. Vet.-Akad. Förh. i. p. 160 (1844); Wagn. Säug. v. p. 44(1855); Peters, P.Z. S. 1865, p. 400 (Angola); id. Reise n. Moss., Säug. p. 4 (Inhambane); Gray, P. Z. S. 1868, p. 182; id. Cat. Monk. B. M. p. 24 (1870); Schleg, Mus. P.-B. vii. p. 79 (1876); Scl. P. Z. S. 1888, p. 564.

Hab. Natal (Wahlberg); Mozambique (Peters); Angola (Welwitsch).

A single example of this scarce Monkey was acquired by the Society in 1888 (see P. Z. S. l.s. c.). It died June 4th, 1890. I now exhibit its skin.

Schlegel has united to this species C. labiatus, Geoffr., but I can see no traces of the white lips in our specimen, and am doubtful about the identification. 
The Samango Monkey has the whole back of a nearly uniform colour, the hairs being yellowish olive, annellated with black; the lower surface of the base of the tail is dirty white, which colour extends round the sides of the tail, leaving a broad line on the upper median surface blackish; the tail-end is black. The outer surface of the arms is black. The outer surface of the legs is grey; the feet are black.

\section{Cercopithecus moloneyi, sp. nov. (Plate XVII.)}

Supraolivaceus, nigricante annellatus, incapiteobscurior; dorso medio ferrugineo nigro annellato; brachiis et manibus nigris; cruribus cinereis nigro mixtis; cauda, nisi ad ipsam basim, nigerrima; corpore subtus pallide fulvo nigricante punctulato : long. corp. 28 poll., cauda 26 poll.

Hab. British Central Africa, north of Lake Nyasa.

I base this apparently new and distinct species upon a skin brought home and presented to me by Dr. J. A. Moloney, one of the surviving members of Stairs's Expedition to Katanga, to whom we are also indebted for our living specimen of Cercopithecus stairsi. Dr. Moloney obtained this specimen from Mr. Whyte at the African Lakes Company's Station of Karonga, at the north end of Lake Nyasa, in April 1892. Dr. Moloney informs me that it was procured by the natives of the surrounding district, which is named Nkonde ${ }^{1}$, the people themselves being called the Wa-Nkonde.

The specimen appears to me to indicate, without doubt, a new species remarkable for its large size, long hairs, and the characteristic ferruginous broad band which covers the lower back. So far as I can tell from the single skin, from which the whole of the bones have been removed, Cercopithecus moloneyi appears to belong to the group of $C$. samango and the allied species, amongst which its large size and red back render it easily distinguishable.

\section{Cercopithecus statrsi.}

Cercopithecus stairsi, Scl. P. Z. S. 1892, p. 580, pl. xl.

$H a b$. Lower Zambesi.

Stairs's Monkey, which I place here for the present, is at once distinguishable from all its allies by the red patches in front of the ears.

\section{Cercopithecus erythrogaster.}

Cercopithecus erythrogaster, Gray, P.Z. S. 1866, p. 169, pl. xvi., et 1868 , p. 182 ; id. Cat. Monk. B. M. p. 128 (1870); Murie, P. Z. S. 1866 , p. 380 (anatomy); Schleg. Mus. P.-B. vii. p. 69.

Hab. West Africa.

We have never been so fortunate as to receive a second specimen of this remarkable Monkey, which may be at once known from its congeners by its red chest, white beard and whiskers, and black frontal band.

1 See 'With Captain Stairs to Katanga,' by J. A. Moloney, p. 264. 
There is a single specimen of the same species in the Leyden Museum, which was formerly living in the Zoological Garden of Rotterdam.

\section{Cercopithecus neglectus.}

Cercopithecus leucocampyx, Gray, Cat. Monk. p. 22.

Cercopithecus neglectus, Schleg. Mus. P.-B. Sim. p. 70.

Hab. White Nile (Petherick).

This is a very distinct species, founded by Schlegel on a single flat skin in the British Museum from the White Nile, which was wrongly referred by Gray to $C$. leucampyx. It is grizzly grey above, and has the haunch banded something like it is in C. diana.

\section{Cercopithecus leucampyx.}

Diane femelle (Cercopithecus diana), F. Cuv. Mamm. i. pl. 16.

Simia leucampyx, Fisch. Syn. Mamm. p. 20 (1829).

Cercopithecus pluto, Gray, P. Z. S. 1848, p. 56, pl. iii., et 1868 , p. 182 ; id. Cat. Monk. B. M. p. 23 (1870); Wagn. Säug. Suppl. v. p. 48 ; Scl. P. Z. S. 1870 , p. 670,1871 , p. 36 , et 1892 , p. 97 (Nyasaland).

Cercopithecus diadematus, Geoffr. in Bélang. Voy., Zool. p. 51 (1834).

Cercopithecus leucampyx, Martin, M. An. p. 529 ; Geoffr. Dict. univ. d'Hist. nat. iii. p. 304 ; Schleg. Mus. P.-B. vii. p. 83 (1876); Wagn. Säug. v. p. 48.

Hab. Angola and Congo (Mus. Lugd.); Nyassaland (Sharpe).

We have hitherto been in the habit of calling this well-marked species of Monkey Cercopithecus pluto. But, as pointed out by Schlegel, it is certainly entitled to bear the name leucampyx of Fischer, which was bestowed upon it twenty years previously. The Pluto or Diadem Monkey is certainly a rare species, although since 1870 , when our first specimen was received, we have had altogether eight specimens in the Gardens. In October 1887 three Pluto Monkeys arrived in the Gardens together, along with a Gorilla, deposited by Cross of Liverpool.

The Pluto Monkey is at once recognizable by its conspicuous white frontal band; the rest of the head and the whole of the limbs and tail are black. It is rather difficult to understand how this very distinct species could ever have been mistaken for the female of the Diana Monkey.

\section{Sect. E. Cercopitheci auriculati.}

Of this section of the genus Cercopithecus, which is distinguished by its long yellowish ear-tufts and the three black lines on the head, three species, or what may be possibly only local subspecies. are distinguishable as follows:-
A. Dorso concolore
B. Dorso postico nigro.
27. erxlebeni.

$\{$ Dorsi fascia angustiore, definita

28. pogonias.

$\{$ Dorsi fascia latiore, confluente

29. nigripes.

Proc. Zool. Soc.-1893. No. XVIII. 


\section{Cercopithecus erxlebeni.}

Cercopithecus erxlebenii, Puch. Rev. et Mag. de Zool. 1856, p. 96 ; Dahlb. Zoolog. Stud. p. 109, t. v. (1856); Gray, P. Z. S. 1868 , p. 182 ; id. Cat. Monk. B. M. p. 23 (part.); Scl. P. Z. S. 1871, p. 36 ; id. List Vert. (1883) p. 10.

Hab. West Africa : Congo (Monteiro).

We received our first specimen of this beautiful species in 1870 , since which date six others have arrived in the Society's Menagerie. It is possible, however, that some of these last may have been referable to two succeeding forms. But the three skins which I exhibit (received 5/9/82, 17/7/85, and 13/10/87) all belong to what I call true erxlebeni, which is without the black stripe on the lower back.

\section{Cercopithecus pogonias.}

Cercopithecus pogonias, Benn. P. Z. S. 1833, p. 67 ; Wagn. Säug. Suppl. v. p. 43 (1855); Gray, P. Z. S. 1868, p. 182; id. Cat. Monk. B. M. p. 23 (1870).

Hab. Fernando Po (Knapp, Thomson, Fraser).

United by Schlegel to C.erxlebeni, but apparently quite distinct, and at once known by the well-defined black dorsal stripe. Type and three other specimens in the British Museum.

\section{Cercopithecus nigripes.}

Cercopithecus nigripes, Du Chaillu, Proc. Bost. N. H. Soc. vii. p. 360 (1860); Gray, P. Z. S. 1868, p. 182.

Cercopithecus pogonias, Schl. Mus. P.-B. Simice, p. 82.

Hab. Gaboon (Du Chaillu).

Like $C$. pogonias but darker, and the black dorsal stripe much broader and less well defined (Mus. Brit.).

\section{Sect. F. Cercopitheci barbati.}

This section, the members of which are at once recognizable by the long beard on the chin, contains only the well-known Diana Monkey and the recently described $C$. brazzae, which may be distinguished as follows :-

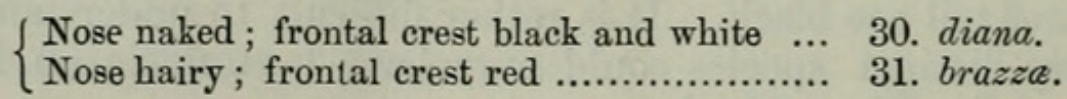

30. Cercopithecus diana.

Simia diana, Linn. Syst. Nat. i. p. 38 (1766).

Cercopithecus diana, Erxleb. Syst. Regn. An. p. 30 (1777); Martin, M. An. p. 523; Geoffr. Dict. univ. d'Hist. nat. iii. p. 304; Wagn. Säug. Suppl. v. p. 48 (1855); Gray, P. Z.S. 1868, p. 182 ; id. Cat. Monk. B. M. p. 22 (1870); Scl. List Vert. (1883) p. 10 ; Schleg. Mus. P.-B. vii. p. 92 (1876); Jentink, Notes L. M. x. p. 12 (Liberia).

$H a b$. Delta of Niger (Fraser); Gold Coast (Pel); Niger (Fraser); Liberia (Büttilkofer). 
The Diana Monkey is by no means scarce in captivity, and during the past thirty years we have had at least 25 specimens of it living in the Society's Monkey-house.

In Gray's Catalogue of Monkeys (p. 22) a "var. ignita" of this species is constituted, as having "the back edge and inner side of the thighs bright red-bay." On May 31st, 1889, we received, as a present, from Col. Wethered of Great Marlow, a female Monkey of this form, of which I now exhibit the skin. Besides the difference above referred to, it will be observed that the white frontal band is not so well marked in this specimen, and that the black of the chin is carried down over the upper part of the beard, which is shorter than in $C$. diana typicus. I propose to designate this subspecies $C$. diana ignitus. Col. Wethered kindly informs me that the sfecimen in question was brought from the Congo by Capt. Moore-Harper in 1886 , so that $C$. diana ignitus is probably a southern form of $C$. d. typicus.

\section{Cercopithecus brazze.} (1886).

Cercopithecus brazzae, Milne-Edw. Rev. Sc. sér. 3, xii. p. 15

$H a b$. French Congoland (Brazza),

I have to thank our Foreign Member M. Alphonse MilneEdwards for kindly sending me a stuffed head of this Monkey for

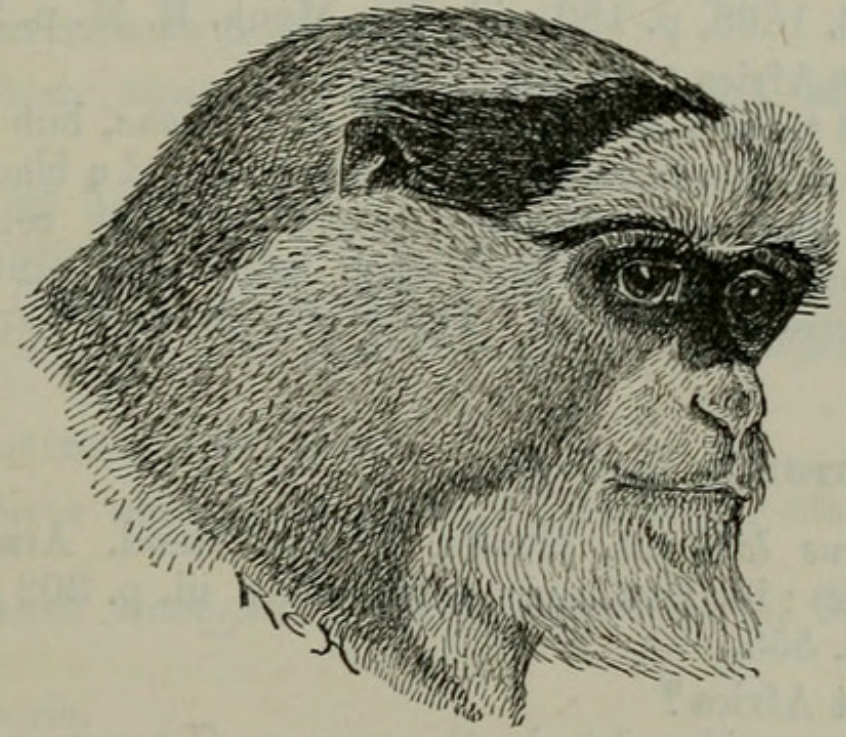

Head of Cercopithecus brazze.

exhibition. It is certainly most remarkable for its elevated red frontal band, which is composed of short erect hairs. This is bordered behind by a broad black band, which extends to the ears on both sides, and in front by a narrow black stripe over each eye. The upper portion of the nose is black, the lower portion, together with the cheeks and lips, is covered with short white hairs. The beard on the chin and throat is long and abundant, formed of white hairs.

This peculiar Monkey was discovered by M. Jacques de Brazza, 
who in 1883 was sent out to French Congo on a special mission to explore the Natural Products of the new French territory between Gaboon and the river Congo.

\section{APPENDIX.-Index specierum mihi nondum obviarum.*}

\section{Cercopithecus boutourlini.}

Cercopithecus boutourlinii, Giglioli, Zool. Anz. x. p. 510 (1887).

Cercopithecus albigularis, Giglioli, Ann. Mus. Civ. Gen. ser. 2, vi. p. 8 (1888).

$H a b$. Central Africa.

This species was based on a specimen transmitted to the Florence Museum from Kaffa, N.E. Africa, by Dr. Traversi. It has been subsequently united to $C$. albogularis.

\section{Cercopithecus flavidus.}

Cercopithecus flavidus, Peters, Reise n. Moss., Säug. p. 3, t. i. $b$. Hab. Mozambique.

"Allied to C. rufo-viridis and C. albogularis."-Peters.

\section{Cercopithecus grayi.}

Cercopithecus grayi, Fraser, Cat. Knowsl. Coll. p. 8 (1850); Gray, P. Z. S. 1868 , p. 182 ; id. Cat. Monk. B. M. p. 22 (1870).

$H a b$. West Africa (Knowsley Coll.).

This is said to be very closely allied to $C$. mona, but to differ in having a yellowish-white spot over each eye, and a black stripe on each side of the head from eye to ear; up the centre of the forehead runs a darkish stripe, each hair being annulated with black and greenish yellow. There are no white spots on the crupper.

\section{Cercopithecus labiatus.}

Cercopithecus labiatus, Geoffr. Compt. Rend. Acad. Sci. xv. p. 1038 (1842) ; id. Dict. univ. d'Hist. nat. iii. p. 302 ; id. Archiv. du Mus. ii. p. 555.

Hab. West Africa?

Sometimes considered to be the same as C.samango. Based on a single menagerie specimen.

\section{Cercopithecus monoides.}

Cercopithecus monoides, Geoffr. C. R. xv. p. 1038 (1842; descr.

* The following species is no doubt a Cercocebus, allied to C. albigena :-

Cercopithecus aterrimus.

Cercopithecus aterrimus, Oudemans, Zool. Gart. xxxi. p. 267 (1890).

$H a b$. Central Africa: Stanley Falls on the Congo. 
nulla); id. Dict. univ. d'Hist.nat. iii. p. 303 (1843); id. Arch. du Mus. ii. p. 558, pl. 31.

$H a b$. Africa.

Described from a menagerie specimen. Allied to C. mona, perhaps the same as $C$. albogularis.

\section{Cercopithecus palatinus.}

Cercopithecus roloway, Erxl. Syst. p. 42 (1777); Geoffr. Dict. univ. d'Hist. nat. iii. p. 304 ; id. Arch. d. M. ii. p. 558.

Cercopithecus palatinus, Wagn. Säug. v. p. 47.

$\mathrm{Hab}$. Guinea.

Like $C$. diana, but with the belly white and the lower back very dark, nearly black.

\section{Cercopithecus picturatus.}

Cercopithecus picturatus, Santos, Jorn. Sci. Lisboa, xi. p. 98 (1886).

$H a b$. West Africa.

This species was based on an individual living in the Zoological Gardens, Lisbon. It belongs to the Spot-nosed section, and is allied to $C$. petaurista, but has the terminal four-fifths of the tail " copper-reddish." It is perhaps $=C$. melanogerys.

\section{Ceroopitheuds signatus.}

Cercopithecus signatus, Jentink, Notes Leyd. Mus. viii. p. 55 (1886).

$H a b$. West Africa?

This species is based on a specimen formerly living in the Zoological Garden, Rotterdam. It belongs to the Spot-nosed group, and is allied to C. petaurista and C. melanogenys.

\section{Cercopithecus stampflit.} Gray).

Cercopithecus melanogenys, Schl. Mus. P.-B. Sim. p. 90 (nec Cercopi (1888).

$H a b$. Liberia.

This species was established on a specimen procured in Liberia by Büttikofer and Stampfli. It belongs to the White-nosed section, allied to $C$. nictitans, but differs from that species in having the underparts white.

10. Cercopithecus ochraceus.

t. i. $a$.

Cercopithecus ochraceus, Peters, Reise n. Moss., Säug. p. 2,

$H a b$. Querimba, Mozambique.

Allied to C. ruber and C. pyrrhonotus, but body above yellowish. 


\section{Cercopithecus Rufo-viridis.}

Cercopithecus rufo-viridis, Geoffr. Compt. Rend. xv. p. 1038 (1842); id. Diet. univ. d'Hist. nat. iii. p. 307 (1843); id. Arch. du Mus. ii. p. 564, t. xxxii.; Wagn. Säug. Suppl. v. p. 40 (1855); Schleg. Mus. P.-B. vii. p. 78.

Chlorocebus rufo-viridis, Gray, Cat. Monk. B. M. p. 25 (1870).

Described from a menagerie specimen, of which the locality was not known; perhaps $=C$. erythrarchus.

\section{Cercopithecus tantalus.}

Cercopithecus tantalus, Ogilby, P. Z. S. 1841, p. 33.

Hab. Africa, loc. ign.

Founded on a specimen formerly living in this Society's Gardens. "Most nearly related to C. sabceus and C.pygerythrus."

\section{Cercopithecus temmincki.}

Cercopithecus temmincki, Ogilby, Library of Entertaining Knowl., Menageries, p. 345 (1838); Martin, M. An. p. 530.

Hab. Guinea.

This species was based by Ogilby on a specimen formerly in the Leyden Museum. Dr. Jentink, the present Director of that Institution, is not able to give me any information about it, stating that he does not believe that it could have been in that collection in 1853, when Temminck published his 'Esquisses Zoologiques sur la côte de Guinée,' as Temminck made no mention of it.

\section{Cercopithecus werneri.}

Cercopithecus werneri, Geoffr. C. R. xxxi. p. 874 (1850); id. Cat. Prim. p. 23 ; id. Arch. d. Mus. v. p. 539, pl. xxvii.; Wagn. Säug. v. p. 42.

Described from living specimens in the Jardin des Plantes. It belongs to the section of Green Monkeys, but is uniform fulvous above and white beneath, with a black face and golden-red tail-end.

\section{Cercopitheous wolfi.}

Cercopithecus wolfi, Meyer, Notes Leyd. Mus. xiii. p. 63 (1891). $H a b$. Central West Africa.

Described from a living specimen in the Zoological Garden of Dresden. It belongs to the "mona" division of Schlegel, but is distinguished from all the other species by its ferruginous hind legs, and by the light patches on the inner side of the thighs and arms. 
3. On Odontaster and the Allied or Synonymous Genera of Asteroid Echinoderms. By F. Jeffrey Bell, M.A., Sec.R.M.S.

[Received February 27, 1893.]

Although I have no intention of pursuing as far as I logically should an investigation which would carry one deep into the perplexities of the classification of the Asteroidea, it seems advisable to say a few words as to Odontaster.

As defined by Prof. Verrill in $1880^{1}$, the characters of this genus are, perhaps, a little obscure ; Mr. Sladen ${ }^{2}$ says of it:- " I have great hesitation in placing Odontaster with the Archasteridæ; it may possibly prove to be more closely allied to the Pentagonasteridæ; in any case it appears to be an annectant genus between the two groups."

An important character in Odontaster is the possession of a "large, strong, sharp, erect or everted tooth."

Among the new genera of Pentagonasteridæ described in the 'Challenger' Report, one, Gnathaster, has the " mouth-plates with a prominent keel, developed aborally into a hyaline spiniform prolongation;" but no ground is given for suspecting that there is any relationship to Odontaster.

In his interesting and instructive Report on the Starfishes of the Mission to Cape Horn, Prof. Perrier diagnoses a new genus, which he calls Asterodon; the "pièces dentaires" in species of this genus carry "chacune un grand piquant vitreux réfléchi en dehors" or support " ensemble un piquant impair, unique, vitreux, interradial" (op. cit. p. K. 132). This genus, though "with an apparent resemblance to the Pentagonasteridæ, is regarded as, on the whole, having more affinity with the Archasteridæ, and reference is made, on the page cited, to Verrill's Odonlaster. On p. K. 188 of the same memoir, Prof. Perrier makes some remarks on the genus Gnathaster, which he finds to be synonymous with, and to have priority as a name over, Asterodon - unless, he adds, "les Odontaster de M. Verrill ne soient des formes génériques identiques, ce qui parait vraisemblable."

More fortunate than either Prof. Perrier or Mr. Sladen, I have been able to make a study of specimens of Odontaster hispidus, presented to the Trustees of the British Museum by the United States National Museum and authenticated by its authority. It soon became obvious that M. Perrier's supposition was correct, and the three names, therefore, are synonyms, Odontaster having a priority of nine years.

Like the English observer, the French one remarks that the forms of this genus are " manifestement des formes de passage." But while the former places his genus with the Pentagonasteridæ, the latter assigns his to the Archasteridæ.

${ }^{1}$ Amer. Journ. Sci. xx. (1880) p. $402 . \quad{ }^{2}$ Chall. Rep. Ast. (1889) p. xxix. 
How is one less qualified than either of these two observers to settle a question on which they, with their ample knowledge, are divided? I, at any rate, pretend to no right or authority, but, as I have to assign the specimens to a systematic place in a list of Asteroidea which I am now preparing, it may be permitted to say why they are to be found with the Archasteridæ.

If we take the definitions offered us in the Introduction to the Report on the 'Challenger' collection of Starfishes, we find we might place Odontaster almost indifferently with either Archasteridæ or Pentagonasteridæ, though there is a slight balance in favour of the former. If we take M. Perrier's latest revision of his scheme of classification, there can be no doubt that the definition of the order Paxillosæ ${ }^{1}$ (op. cit. p. K. 71) applies to Odontaster very much better than does the definition of the Valvulatæ; and the Pentagonasteridæ belong to the latter, the Archasteridæ to the former of these two orders.

But at this point I must stop or I shall be drawn into a discussion as to the classification of the subdivisions of Asteroids, which would be far too lengthy for me just now. Only let me point the moral that the present state of the classification of Asteroids is not as satisfactory as one would hope to find it after the labours of two industrious zoologists for five or more years, and that Odontaster is sufficient to prove that no classification can be satisfactory which allows of a wide gap between the Archasteridæ and the Pentagonasteridæ.

A list of the species of Odontaster with the synonyms may be useful.

\section{ODONTASTER.}

Odontaster, Verrill, Am. J. Sci. xx. (1880) p. 402.

Gnathaster, Sladen, Chall. Rep. Ast. (1889) p. 285.

Asterodon, Perrier, Miss. Cap Horn, Echinodermes (1891), p. K. 132 .

\section{Odontaster belLi.}

Pentagonaster belli, Studer, Anhang zu Abh. k. Akad. Wiss. Berlin, 1884 (1885), p. 31.

Prof. Perrier thinks this may be a synonym of Odontaster singularis, but the ventral plates of that species are in no way paxilliform; the adambulacral spine of 0 . belli appears to be specially modified, and in the distal fourth of the arm the intermediate actinal plates are wanting, For these reasons separation appears to be, at present, the safe course.

2. Odontaster dilatatus.

Pentagonaster dilatatus, Perrier, Arch. Zool. expér. v. (1876) p. 33.

Gnathaster dilatatus, Sladen, Chall. Rep. Ast. (1889) p. 750.

1 May I take this opportunity of remarking that "paxilli," and not "paxillæ," is the correct form of the name of these plates? 
3. Odontaster elongatus.

Gnathaster elongatus, Sladen, Chall. Rep. Ast. (1889) p. 288.

\section{Odontaster granulosus.}

Asterodon granulosus, Perrier, Miss. Cap Horn(1890), p. K. 132. laris.

But for its pedicellaria this species is very close to 0 . singu-

\section{Odontaster grayi.}

Calliderma grayi, Bell, P.Z. S. 1881, p. 95.

Pentagonaster paxillosus, id. (not Gray) t.c. p. 95.

Gnathaster grayi, Sladen, Chall. Rep. Ast. (1889) p. 750.

Asterodon pedicellaris (pars), Perrier, Echinod. Miss. Cap Horn (1891), p. K. 135.

Asterodon grayi, id. t.c. p. K. 138.

After a very careful and detailed examination of the descriptions and the specimens at my disposal, I have come to the conclusion that :-

(1) What in 1881 I called the young of Pentagonaster paxillosus, Gray, is not so, for $P$. paxillosus has two long (? glassy) spines at each oral angle, while the Magellan specimen has but one.

(2) P. paxillosus, Bell (1881), is clearly the same as those specimens of Asterodon pedicellaris which have not the remarkable "pedicellariæ" said by M. Perrier to be found in some members of that species, with regard to which I should be glad of more detailed examination; and I give, therefore, the synonymy as above.

(3) M. Perrier's account of his example of " Calliderma grayi," which is larger than the two small specimens in the British Museum, is sufficient to assure me that we have here to do with one species under three specific and three generic names!

(4) A comparison of the original of Mr. Edgar Smith's Pentagonaster meridionalis with M. Perrier's descriptions shows that there is no reason whatever for regarding it as synonymous with $A$. pedicellaris. The last-named species appears to me to be divisible into two; so far as I can form a mental picture of the "pedicellariæ" described by Prof. Perrier, their presence or absence is a point of sufficient importance to justify specific distinction. With regard to 0 . meridionalis, Mr. Smith is not affected by the complaint of M. Perrier that he "ne signale pas" the remarkable pedicellariæ, for they are not present on the specimen which formed the basis of his description. On the other hand, Mr. Sladen is quite correct in pointing out that there are no pedicellariæ on the upper surface of the same specimen.

6. Odontaster hispidus.

Odontaster hispidus, Verrill, Am. J. Sci. xx. (1880) p. 402.

7. Odontaster meridionalis.

Astrogonium meridionale, E. A. Smith, Ann. \& Mag. Nat. Hist. xvii. (1876) p. 109. 
Pentagonaster meridionalis, id. Phil. Trans. 168. (1879) p. 276.

Gnathaster meridionalis, Sladen, Chall. Rep. Ast. (1889) p. 287.

Gnathaster pilulatus, id. t.c. p. 292.

\section{Odontaster miliaris.}

Astrogonium miliare, Gray, P.Z. S. 1847, p. 79.

Gnathaster miliaris, Sladen, Chall. Rep. Ast. (1889) p. 750.

I include this species on Mr. Sladen's authority ; the only specimen of it that I have seen, that described by Dr. Gray, has the mouth-parts so poorly preserved that I cannot say whether or no it had the spines which are characteristic of this genus.

\section{Odontaster paxilloosus.}

Astrogonium paxillosum, Gray, P.Z.S. 1847, p. 79.

Gnathaster paxillosus, Sladen, Chall. Rep. Ast. (1889) p. 750.

\section{Odontaster pedicellaris.}

Asterodon pedicellaris, Perrier, Miss. Cap Horn (1891), p. K. 135.

For the limits of this species, see the remarks under 0 . grayi.

\section{Odontaster Singularis.}

Goniodiscus singularis, M. Tr., Arch. f. Nat. 1843, p. 116.

Pentagonaster singularis, Perrier, Arch. Zool. expér. v. (1876) p. 38.

Gnathaster singularis, Sladen, Chall. Rep. Ast. (1889) p. 750.

Asterodon singularis, Perrier, Miss. Cap Horn (1891), p. K. 134.

Mr. Sladen includes Goniodiscus verrucosus, Phil., under Gnathaster with a sign of doubt.

4. On a new Genus and Species of Acari found in Cornwall. By A. D. Michael, F.L.S., F.Z.S., P.R.M.S., \&c.

[Received March 11, 1893.]

(Plate XVIII.)

In November 1892 I was staying near the Land's End, Cornwall : in one of the small rocky bays which are found along this granite coast a little stream of fresh water comes down from the cliffs in the middle of the bay; at the edge of the stream, where it only trickled, and near enough to the sea to be within the influence of wind-carried spray, some considerable patches of the small green water-weed Cladophora fracta were growing. Amongst this weed I found examples of several species of Acarina, and was taking the 


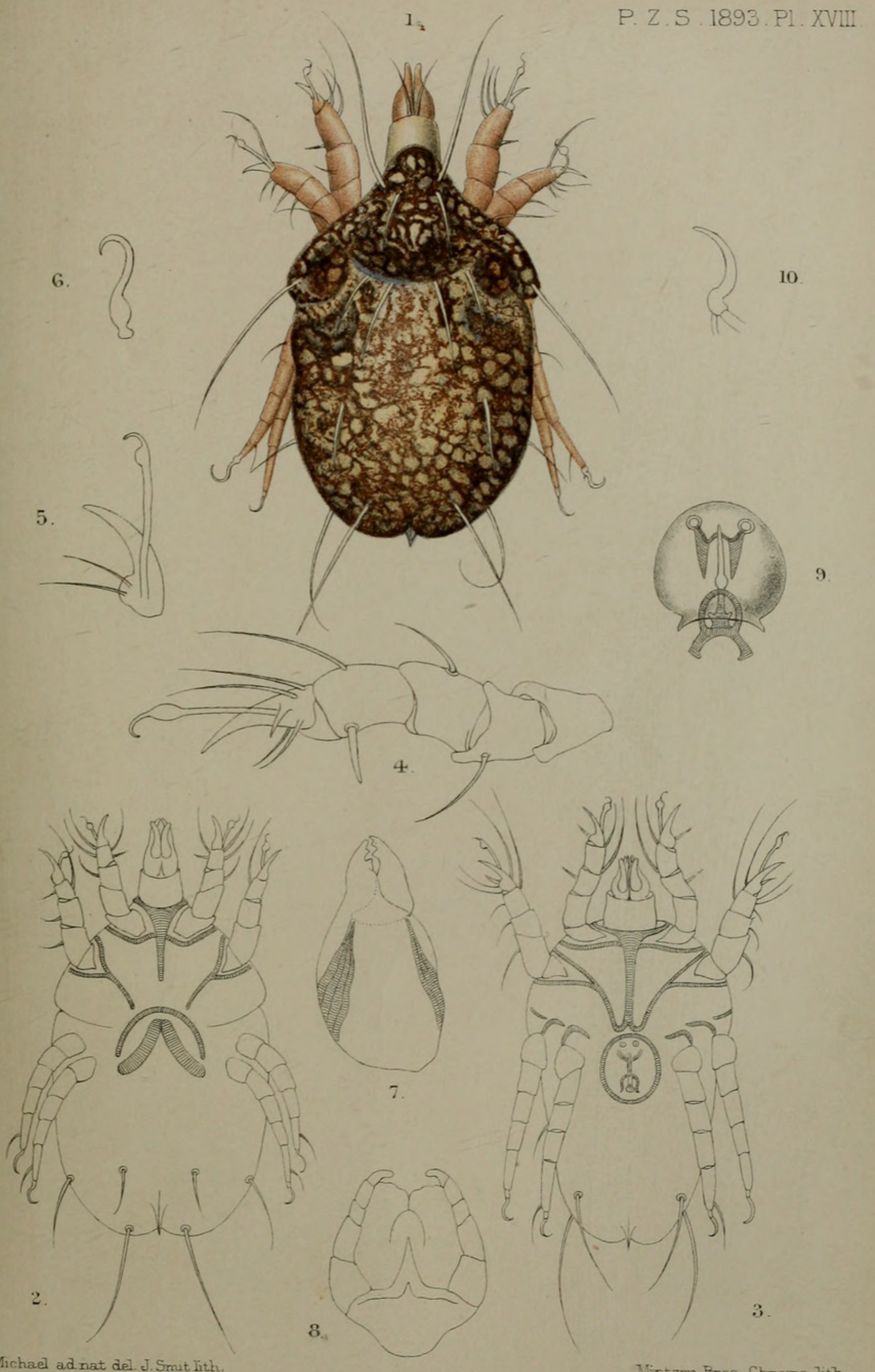

A D Michael ad nat del. J. Smit lith

Mintern Bros. Chromo lith. 
UAAL HISI 
opportunity of studying the anatomy of two of these species. For this purpose I required frequent fresh supplies of the creatures, but, unfortunately, before I had completed my investigations, a two days' storm of violent rain and wind came, and when I revisited the stream I found almost all the alga washed away and not an Acarus left in what remained. Under these circumstances I began to search for other patches of the Cladophora, and found a largish quantity growing on the face of the cliff near the horn of the bay, in a place somewhat difficult of access, nearer to the sea than the other, but higher up the cliff; a very thin thread of fresh water trickled down the cliff here, keeping the alga moist, and the spray of the sea would dash there in rough weather, and probably more or less would be carried there whenever the wind was from the sea, its most frequent direction. It was a warm corner facing south. The weed was abundant and in good condition, having been protected from the storm; but, to my surprise, I did not find in it a single specimen of either of the species which I was looking for, but, on the other hand, I did find examples of two other totally distinct species which I had not ever before found in the Cladophora either at the stream in the middle of the bay or elsewhere. The first was in great numbers and in all stages ; it was one of the Halicaridæ.

More careful examination with a microscope disclosed that there was also a second and much smaller species present in considerable numbers ; it is, I believe, unknown, and the object of this paper is to record it. The creature, in spite of its minute size, has structural peculiarities which seem to me to render it particularly interesting. It belongs to the family Tyroglyphidæ. I thought at first that I had a new species of the genus Hericia, and that genus is certainly its nearest ally ; but it is not possible to include it in that or any other existing genus. The great and singular difference of the two front pairs of tarsi and claws, the different position of the anus, and the absence of the strong sexual dimorphism found in Hericia, besides other points, distinguish it from that genus. There is only one recorded species of Hericia, viz. H. robini (Canestrini ex Robin), a very singular creature of a flattened diamond-shape (the male especially) which wades in the sap which exudes from elm-trees where the bark has split. The present species shares the flattened diamond-shape and the wading habits of H. robini, although the habitat is so very different.

The great peculiarity and interest of the present species consists in the tarsi and claws. The Tyroglyphidæ usually have rather slender tarsi and from the actual end of each tarsus springs a single claw either with or without a caruncle : where the caruncle is present the claw is usually small; where it is absent, as in the genus Hericia, the claw is usually larger and more powerful. The claw generally consists of hard colourless chitin, and is a strongly curved hook with a very short, straight, hard, and solid peduncle, at the proximal end of which a small ball-like swelling serves to give attachment to tendons. Hook, peduncle, and ball 
are all in one piece and quite hard and stiff; all the claws of Hericia are of this nature. The two hind pairs of legs of the present species have tarsi and claws fairly similar to those of Hericia, except that the shaft is a little more bulbous; the claws are large, of the ordinary type, and spring from the ends of the tarsi. The two front pairs of legs have an entirely different termination; the tarsi are very powerful, strongly curved downward, particularly at the distal end, and formed of stronger and denser chitin than the rest of the legs; they end in blunt points, and have the appearance of the dactylopodite in some Crustaceans. They form efficient climbing-organs, and the Acarus practically climbs entirely by their aid. I watched it climbing some dozens of times; it got the curved ends of its tarsi on to or over the edges of small pieces of stone or weed, and clinging to these slowly dragged itself up. From the side, not the end, of each tarsus springs a long, hyaline, slender peduncle, which projects considerably beyond the tarsus ; this peduncle is flexible in all directions-not in the sense that it yields when it touches anything, for in effect it seldom does touch anything except very lightly, but in the sense that it has special motion of its own and can be flexed and turned in any direction at the will of the creature; indeed, it is almost constantly in motion. The distal end of this peduncle swells suddenly and forms a bulb, at the end of which is a very minute claw; the bulb can be turned upward and downward, carrying the claw, but the claw has not any motion separate from the bulb. This claw and peduncle are not used in clinging or walking at all ; they seem to have become wholly tactile organs; the creature clings with the tarsus and then appears to feel about with the claw by turning and bending its flexible peduncle in all directions until it finds a suitable place to put the tarsus for the next step, then it moves the tarsus and the process recommences, being of course done by opposite legs alternately. I am not aware of anything at all similar in the structure and habits of any of the Acarina. I propose calling the genus "Lentungula," and the species L. algivorans.

\section{Genus Lentungula ${ }^{1}$.}

Tyroglyphidæ without marked sexual dimorphism; with the body flattened dorso-ventrally; with the tarsi of the two front pairs of legs strongly curved, gradually diminished, ending in points, and used as climbing-organs. The claws of the same pairs of legs minute and mounted on long flexible peduncles springing from the sides of the tarsi and capable of being flexed at the will of the creature. Tarsi of two hind pairs of legs of the ordinary type, ending in large single claws without caruncles. With terminal anus formed of two upright plates lying against each other. Genital aperture in both sexes near the middle of the body between the coxæ of the fourth pair of legs.

1 Lentus, flexible; ungula, a little claw. 


\section{Lentungula aLgivorans. (Plate XVIII.)}

Average length without mandible about $\cdot 38 \mathrm{~mm}$.

Greatest breadth about $\cdot 20 \mathrm{~mm}$.

Length of legs 1st pair about $\cdot 13 \mathrm{~mm}$.

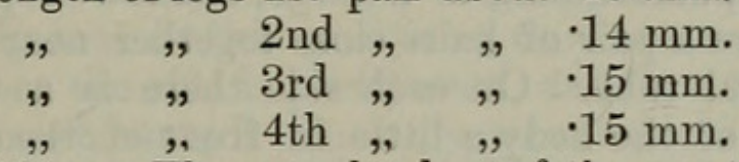

Colour.-The actual colour of the creature, if it had been fasting for a long time, would probably be almost entirely light yellowish, but as ordinarily seen it is dark olive-brown with very numerous light yellowish spots and markings. The yellowish colour is chiefly in spots and spaces surrounded with the olive, but the spots are not arranged in any definite pattern; although a few spots on the cephalothorax have a tendency to be permanent, the whole of the markings are most irregular and varying. The olive-brown colour greatly predominates, and some specimens are almost wholly of that tint. The colour apparently arises from the diffusion of food material or products, it is not pigment in the cuticle; this can be demonstrated by placing a dark specimen in a drop of water on a glass slip under the microscope and placing a cover-glass over it; as the water evaporates the cover will be slowly drawn down, producing pressure upon the creature; the result of this will be that what appears like the whole contents of the body are gradually discharged from the anus, and the opaque dark creature becomes yellowish white and transparent. During life the brown colour does not, however, look like food-contents, it has every appearance of being the true colour of the greater part of the body. The rostrum and legs are always pale pinkish yellow.

Texture polished.

Shape.-This also depends considerably upon whether the creature is fully fed; when it is so the distinctive form is lost, and the Acarus becomes almost a roll with little shape in it, but when not quite so fully fed the form is rather striking. The cephalothorax is slightly broader than the abdomen, but much thinner dorsoventrally, so that where the two join the dorsum of the abdomen stands high above the cephalothorax. There is a sharp indentation in the lateral edge of the creature, where cephalothorax and abdomen join; behind this the abdomen of the female is almost sack-shaped; that of the male narrows a little more posteriorly ; in both sexes the hind margin is indented in the middle, so that each side forms a rounded lobe.

Cephalothorax.-The rostrum is a smooth tube or collar, long for the family; the strong chelate mandibles project considerably; each arm of the chela is tridentate (fig. 7). The five-jointed palpi (fig. 8), of the ordinary type, are adherent to the membranous maxillary lip, in the centre of and below which is a chitinous triangular sclerite which might possibly be considered to represent a labium. The central portion of the cephalothorax, behind the rostral tube, forms a large, rounded, fleshy lobe which overhangs the 
rostrum. The hinder part of the cephalothorax widens greatly, its edge being the double curve known as the line of beauty. This edge is formed by a large raised roll; the median portion of the cephalothorax is also raised, but between the two, in the hinder part of the cephalothorax, is a large, shallow depression or dimple. There are a pair of hairs close together near the anterior edge of the rostral tube. On each side there is a very long hair near the edge of the body a little in front of the first leg, a similar hair near the posterior corner of the cephalothorax, and a shorter one about midway between them, also one pair on the dorsum of the cephalothorax ; these, and all other hairs on the creature are simple and setiform.

Abdomen.-The anterior edge (progaster) has a somewhat exceptional form; the central portion (about half the width) projects boldly into the cephalothorax, is concave anteriorly, and runs out laterally so as to form a short horn or point. From the central projection the line on each side of the body runs back at an angle, but this portion also is concave anteriorly; it forms a raised roll with a large shallow depression or dimple behind it like that on the cephalothorax. When the creature is very fully fed all these depressions vanish, they also disappear after death. There are two pairs of hairs on the central projection of the progaster, the inner pair are the longer. There are also two other pairs of hairs on the notogaster (the hinder the longer), and two hairs on each lateral edge (the hinder the longer). The anus forms a short, median, posterior projecting point when seen from above, but a long slit when seen from the ventral surface; it is formed of two thin blades on edge lying close against each other, but capable of being separated widely posteriorly.

Underside (figs. 2 and 3).-The sternum is a triangular plate sending out band-like projections on each side parallel to the edge of the rostral collar, and a similar but straight piece posteriorly in the median line; this is longer in the male than the female. The epimera of the first pair of legs are formed by the lateral projections of the sternum and a branch arising from the sternum and passing behind the legs. Those of the second pair of legs are somewhat $\mathrm{Y}$-shaped sclerites, which in the male are joined at their posterior ends to the posterior end of the sternum by short cross pieces. In the female they are wider apart and not attached. The epimera of the third and fourth legs are short right-angled pieces in the male. The vulva is between the two posterior pairs of legs ; but advances more forward than the insertion of the legs; it is protected anteriorly by a large semi-annular sternite, and has well-marked chitinous labia. The male organ (fig. 9) lies rather further back; it is protected by a slightly elliptical (almost circular) plate, slightly truncated behind. This plate covers the longish curved penis (fig. 10) and the somewhat elaborate skeleton which supports it (fig. 9). This consists of a horseshoe-shaped sclerite with thick projecting posterior ends joined by a broad band, from a central projection of which the penis arises; the anterior end of 
the organ, when at rest, is supported in a notch formed by two short rods attached to triangular blade-like sclerites on edge.

The legs are short, the posterior pairs not reaching the hind margin of the body; the two front pairs are almost blade-like, so that when seen on edge they appear almost linear, but they are rarely seen in this position; they are usually turned at an angle so that the side is partly seen, and thus they look very broad; they are much curved. The only remarkable feature is the tarsus (fig. 5), which in these two pairs is strongly curved and bluntly pointed, so that the whole joint forms a great claw, and it is by this that the creature climbs. It, however, is not the true claw, that exists in addition; from the side, not the end, of the claw-like tarsus springs a fine transparent, flexible tube which projects considerably beyond the tarsus ; this tube ends distally in a small hollow ball, from which the very minute, but perfectly distinct, real claw arises. The tube can be flexed in almost any direction at the will of the creature; the ball also is capable of separate articulate motion upon the tube, but the claw does not seem capable of movement separately from the ball. I have not seen this apparatus used in clinging, but it is in continual special movement as the creature moves or feels about. It would seem to have become a tactile organ or one for collecting food. There is a short curved spine on the underside of the tarsus, a strong spike on the underside of the tibia, and some hairs, the arrangement of which may be seen from the drawings. The two posterior pairs of legs are quite different from the anterior : they are ordinary rounded legs, rather small, without any special feature; the tarsi are of the ordinary nature, and are terminated by large, single, curved claws (fig. 6).

Habitat. I found numerous specimens in a patch of green alga (Cladophora fracta) growing where the fresh water of a small stream trickled over the face of the granite cliffs within reach of the spray of the sea, near the Land's End, Cornwall. I have not found it elsewhere.

\section{EXPLANATION OF PLATE XVIII.}

All the figures represent Lentungula algivorans.

Fig. 1. Adult 9 seen from above, $\times 150$.

2. Adult + seen from below, $\times 150$.

3 . Adult $\delta$ seen from below, $\times 150$.

4. Second left leg (drawn from the $\sigma^{\star}$, but similar in both sexes), side view, $\times 320$.

5. Tarsus of 1 st left leg, $\times 320$.

6. Claw of 4 th leg (drawn from $\delta$, but sexes similar), $\times 320$.

7. Left mandible of $q$ seen from the inner side, $\times 320$.

8. Maxillary lip, palpi, and (?) labium seen from below, $\times 320$.

9. Penis and penial skeleton and sclerites seen from below, $\times 320$.

10. Penis seen from the side, $\times 320$. 


\section{Notes on Variation and Development of the Vertebral} and Limb-Skeleton of the Amphibia. By G. B. Howes, F.L.S., F.Z.S., Assistant-Professor of Zoology, R. Coll. Sci. Lond.

[Received March 14, 1893.]

Vertebral Column.-Numerical variation of the vertebræ of Amphibia has been from time to time recorded by various authors, and in dealing with the living Anura, Adolphi, as the result of a recent extensive enquiry ${ }^{1}$, has been enabled to classify the types of variation met with into three orders, as chiefly determined by the fusion of adjacent vertebræ throughout this or that definitely restricted region. There has recently come into my possession the skeleton of an edible Frog (Rana esculenta) in which (fig. 1 a) the eighth and ninth vertebræ were immovably united; and although this union is in itself an apparently trivial matter, the fact that Adolphi found but one such case in 212 individuals of the Toad (Bufo var.) specially examined ${ }^{2}$, is sufficient testimony to the rareness of the occurrence to warrant its being placed on record. So far as I am aware, Adolphi's example and those herein recorded are the only ones in which this particular fusion has been yet described, the majority of recorded variations having chiefly involved the head of the urostyle and sacrum. Rare as the fusion of the terminal vertebræ of the living Anura would thus appear to be, it is a remarkable circumstance that Walterstorff, who has shown ${ }^{3}$ the Tertiary genus Palcoobatrachus to be possessed of a compound sacrum of usually three vertebræ, regards the fusion of these as normal and characteristic of the genus.

On general morphological grounds there is good reason, as need hardly be pointed out, for associating the compound sacrum and the fusion of the sacral vertebræ together; and it might therefore reasonably be expected that in the Frog herein described (figs. $1 a$, $1 b$ ) a second sacral transverse process should appear on one or both sides. Such, however, was not the case; for the transverse processes of the last two vertebræ were in no way exceptional either in disposition or relationship. This is the more remarkable, as the 8th vertebra of this animal is known to occasionally enter into the composition of the sacrum on one or both sides, while still free and independent. In the Toad described by Adolphi ${ }^{4}$, the Palæobatrachoid condition was much more nearly realized, as the fusion had involved the transverse processes of the 8th and 9th

1 Morpholg. Jahrb. Bd. xix. pp. 331-375. As this author's list of references is incomplete, the contributions of Sasserno and others having been apparently overlooked, I am compelled to refer the reader to an earlier paper of my own (Journ. Anat. \& Phys. vol. 24. p. xvi app.) for a full record up to the time of writing.

${ }^{2}$ Loc. cit. p. 351 .

3 Jahrb. naturwiss. Vereins, Magdeburg, 1885-86.

${ }^{4}$ Loc. cit. p. 366 , pl. xii. fig. 4. 
vertebræ on the right side. On searching through an accumulation of Frogs' bones in my possession, I found a specimen (fig. $2 b$ ) which, except for certain subtle and altogether unimportant differences of an adaptive nature, closely parallels Adolphi's Toad; and I am indebted to my demonstrator, Mr. M. F. Woodward, for a backbone in which the opposite (left) side, instead of the

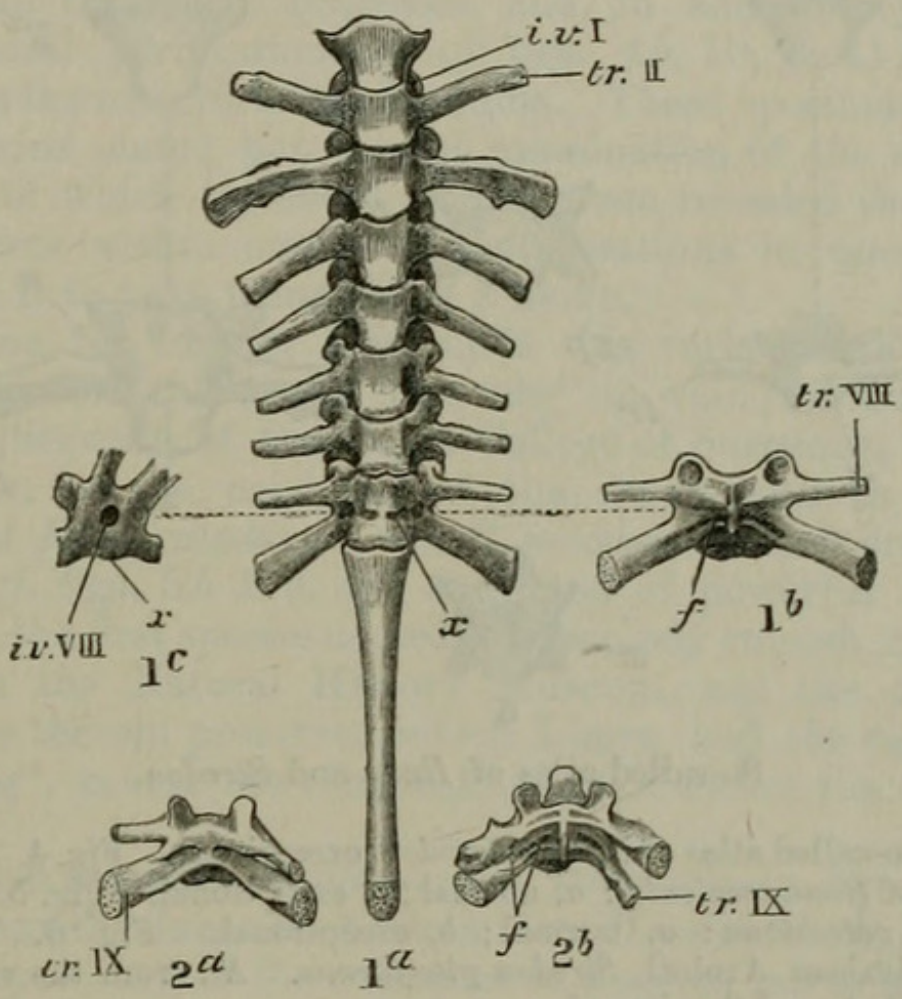

Vertebral column of Rana esculenta.

Fig. $1 a$. The vertebral column of an individual in which the last two vertebræ had completely united, ventral aspect. Fig. $1 b$. The united 8th and 9th vertebræ of the same, dorsal aspect. Fig. $1 c$. The same, lateral aspect. Fig. $2 a$. The correspondingly united 8 th and 9 th vertebræ of another individual, having a compound sacrum on the left side. Fig. $2 b$. A similar case to $2 a$, but with the compound sacrum on the opposite side. $2 a$ and $2 b$, dorsal aspect. All $1 \frac{1}{3}$ nat. size.

$f$, furrow, denoting the point of fusion of adjacent parts ; $i . v$, intervertebral foramen; $t r$, transverse process; $x$, eminence at the point of fusion of adjacent vertebral bodies.

right, was similarly modified (fig. $2 a$ ). In his specimen the 9 th transverse process furnished the sacral articulation on the non-affected side, as with Adolphi's Toad; while in my own (fig. $2 b$ ) the eighth fulfilled that function.

Except for a relative diminution in the length of its urostyle, and for the fusion of parts already referred to, the Frog's backbone first described (fig. $1 a$ ) was in no respect structurally abnormal. Its anterior three vertebræ were, however, far less freely movable than is normally the case; and in this they anticipate as it were the greater fusion of these bodies so frequently met with in Ceratophrys

Proc. Zool. Soc.-1893, No. XIX. 
and certain other genera, and the more regular if not diagnostic ankylosis of the first two vertebræ of the living Pipa, Xenopus, Pelobates $^{1}$, and others, and of the extinct Palceobatrachus ${ }^{2}$. The fact that Ceratophrys and Pelobates, in which this tendency towards a greater fusion is well marked, are possessed of a relatively short

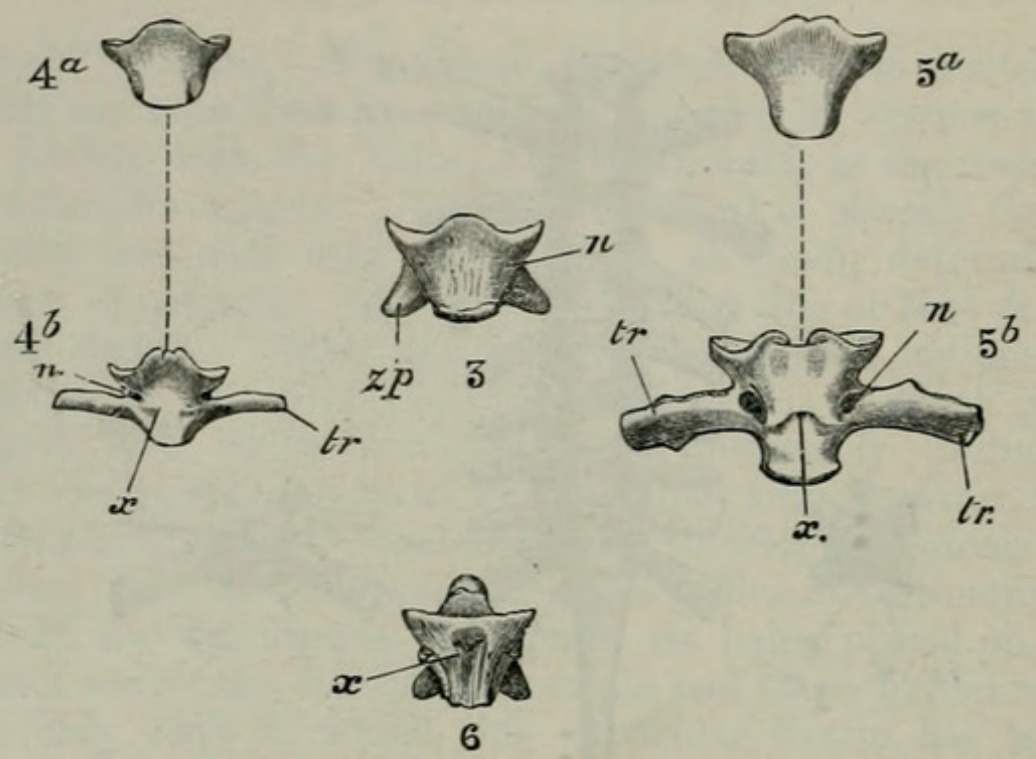

So-called atlas of Rana and Siredon.

Fig. 3. The so-called atlas of Rana macrodon, exceptional. Fig. 4. The so-called atlas of Rana esculenta : $a$, normal ; $b$, exceptional. Fig. 5. The same in Rana catesbiana: $a$, normal; $b$, exceptional. Fig. 6 . The same in the Mexican Axolotl, Siredon pisciformis. All from the ventral aspect. Figs. 3, 4, and 6 enlarged.

$n$, nerve-aperture for exit of trans-atlantal nerve ; $t r$, transverse process; $x$, eminence at point of fusion of adjacent vertebral bodies.

urostyle, invests the aforenamed anticipation with an amount of interest, by way of suggesting that the reduction in length of the urostyle and the vertebral ankylosis may be associated modifications.

In the majority of Anuran skeletons that I bave examined, in which co-ossification of adjacent vertebræ had been effected, all traces of their original lines of demarcation were lost on the ventral surface, the centra passing insensibly into one another. In the Frog first described this was otherwise, for its vertebral column when viewed from beneath (fig. $1 a$ ) or from the side (fig. $1 c$ ), revealed a couple of eminences $(x)$ at the point of fusion of the two terminal vertebræ.

There is no variation to which the Amphibian vertebral column

1 Cf. Hoffmann, in Bronn's Klassen und Ordnung. d. Thier-Reichs, “Amphibien," (Bd. vi.) p. 57.

${ }_{2} \mathrm{Cf}$. Walterstorff, op. cit., and Adolphi, los. cit. p. 362. I have observed a similar fusion of the first two vertebræ in individuals of Rana guppyi and $R$. catesbiana. 
is liable at all approximate in interest to that of the occasional appearance of transverse processes on the first vertebra; but, with the exception of a casual mention of a case in Rana esculenta by A. G. Bourne ${ }^{1}$, it has remained unnoticed. His specimen was very abnormal in other respects; but I am in possession of two backbones of the same species in which, while the last eight vertebræ were perfectly normal, the first one or "atlas" bore transverse processes, aud, in addition (fig. $4 b$ ), a pair of lateral perforations ( $n$ of figs. $4 b, 10, \& 11$ ) disposed serially with the intervertebral foramina. These specimens reached me in the dried state; but careful examination of the remains of the soft parts which lay about one of them revealed the presence of nerve-fibres within one of the perforations in question, and thus proved it to have transmitted a nerve.

On seeking for further light upon this variation, I have dissected certain of the larger Ranoids ${ }^{2}$ in vain; but my friend Prof. Chas. Stewart, of the Royal College of Surgeons, has called my attention to the existence of the nerve-exits in the only specimens of Rana catesbiana and $R$. macrodon which his Museum possesses (cf. figs. $5 b \& 9, \& 3 \& 8$ ), and of powerful transverse processes in the first species named. Strangely enough, neither the skeletons in the Natural History Museum, nor the carcases of these species therein preserved which I have had the opportunity of dissecting ${ }^{3}$, reveal the remotest traces of either the one or the other.

Hyrtl called attention twenty-eight years ago, in his celebrated Monograph on the Japanese Salaniander (Megalobatrachus [Cryptobranchus] japonicus), to the existence of a spinal nerve which perforated the arch of the "atlas;" and Humphry, six years later, described the nerve more fully " as the "sub-occipital," tracing it to a distribution to the "foremost portion of the sub-vertebral rectus" muscle. Fischer had (in 1864) already described a similar nerve $^{5}$ in Menobranchus, believing it to be peculiar to that animal among Urodeles; and it is interesting to note that he traced it to a distribution in the "occipitalis minor" muscle. Hyrtl, in accordance with the facts of the case, was led to regard the socalled "atlas" of the Amphibia as a product of fusion of the "atlas and epistropheus" of the higher Vertebrata ; but this revolutionary conception has been almost lost sight of, except for its acceptation by Hoffmann ${ }^{6}$ and so far as the work of Albrecht ${ }^{7}$ and Stöhr ${ }^{8}$, alluded to below, may bear upon it. Neither it nor any facts concerning

1 Quart. Journ. Micr. Sci. vol. xxiv. p. 86.

2 Calyptocephalus grayi, Leptodactylus pentadactylus, and Rana guppyi.

3 For permission to do this my best thanks are tendered to Dr. A. Günther,

F.R.S., and my friend Mr. G. A. Boulenger.

4 Journ. Anat. \& Phys. vol. vi. p. 48 (1870).

5 'Anat. Abhandlg. ü. d. Perennibranchiaten und Derotremen,' Hft. i. p. 158 (Hamburg, 1864).

6 Bronn's Thier-Reich, Bd. vi. p. 54.

7 Zool. Anz. 1880, p. 477.

8 Zeitschr. f. wiss. Zool. Bd. xxxiii. p. 477, and Bd. xxxri. p. 68. 
it are alluded to in Cope's recent 'Batrachia of North America', except that he refers to the odontoid process of the Urodela (p. 29) as the "body of the pro-atlas;" Adolphi is silent on the topic, assuming the "sub-oceipital" nerve to be absent in all Anura ${ }^{2}$; while Fürbringer, in a laborious investigation into the comparative anatomy of the shoulder-muscles, has recorded ${ }^{3}$ his inability to find a nerve either passing between the skull and the first vertebra or perforating the arch of the latter, in any Anuran which he dissected (Pipa excepted).

Not the least interesting feature in the transverse-process bearing "atlas" of Rana catesbiana (fig. $5 b$ ) and $R$. esculenta (fig. $4 \mathrm{~b}$ ) is the presence on the under surface of each of a couple of eminences, well-nigh indistinguishable from those present in the specimen herein described (fig. $1 a$ ) at the point of fusion of the 8 th and 9 th vertebræ $(x)$. Rana macrodon reveals no such peculiarity (fig. 3), but in the Axolotl, in which also I find a "suboccipital " nerve may be present, a deep lyriform depression occurs at the corresponding point ( $x$, fig. 6$)$, bounded in front by a median tuberosity. While, on exclusively anatomical grounds, these points of similarity support the principle of Hyrtl's conclusion, the facts of comparative morphology ${ }^{4}$ that have in recent years shown the hypoglossus nerve-bearing region to be incorporated in the occiput of the Amniota, together with those which are rendering it more and more clear that the os odontoideum of these animals is a true centrum, and the so-called "body" of their atlas an intercentrum ${ }^{5}$, forbid further comparison between the "atlas" of the Amphibia and either the atlas or epistropheus of the higher Vertebrata.

The nerve passing through the arch of the "atlas" in some Urodela conforms, so far as is known, to the characters of a true spinal nerve; as described by Humphry in Megalobatrachus, it has the relations rather of a ventral than a dorsal ramus of a typical nerve of the trunk; while, as described by Fischer for Menobranchus, the reverse would appear to hold good. Prof. Stewart informs me that in Rana catesbiana (the "atlas" of which is herein figured) he traced it to the muscles of the hyoid region.

Stöhr has recently shown ${ }^{6}$ that the odontoid process of the Amphibian (Triton) is a primarily independent derivative of the eranial notochord; and he lays much stress ${ }^{7}$ upon the conclusion that the homologues of the hypoglossus and accessorius nerves of the higher Vertebrata are to be sought in the anterior spinal nerves of the lower ones. If this be accepted, the known

${ }^{1}$ Bull. U.S. Nat. Mus. no. 34 (1889).

${ }^{2}$ Loc. cit. p. 316.

3 Jenaische Zeitschr. Bd. vii. p. 286 (1873), and Bd. viii. p. 180 ( $f f$. v. Thering, infra, p. 273).

${ }_{4}^{4}$ For a résumé of these see P. Z. S. 1890 , p. 358.

5 Cf. especially Baur, Biolog. Centralbl. Bd. vi. p. 359, and Boulenger, Ann. \& Mag. Nat. Hist. ser. 6, vol. iii. p. 140.

${ }^{6}$ Zeitschr. f. wiss. Zool. Bd. xxxyi. p. 99.

7 lbid. Bd. xxxiii. p. 518. 


\section{$2 \mathrm{BHL}$ Biodiversity Heritage Library}

Flower, William Henry. 1893. "March 14, 1893." Proceedings of the Zoological Society of London 1893, 237-278.

https://doi.org/10.1111/j.1469-7998.1893.tb00560.x.

View This Item Online: $\underline{\text { https://www.biodiversitylibrary.org/item/97156 }}$

DOI: https://doi.org/10.1111/j.1469-7998.1893.tb00560.x

Permalink: https://www.biodiversitylibrary.org/partpdf/72810

\section{Holding Institution}

Natural History Museum Library, London

\section{Sponsored by}

Natural History Museum Library, London

\section{Copyright \& Reuse}

Copyright Status: Public domain. The BHL considers that this work is no longer under copyright protection.

This document was created from content at the Biodiversity Heritage Library, the world's largest open access digital library for biodiversity literature and archives. Visit BHL at https://www.biodiversitylibrary.org. 